\title{
Price discrimination in informal labor markets in Bogotá: an audit experiment during the 2018 FIFA World Cup
}

\author{
Paula Zamora ${ }^{1}$, César Mantilla ${ }^{2^{*}}$ (D) and Mariana Blanco ${ }^{2}$
}

\begin{abstract}
We conducted an audit experiment to examine whether street vendors in Bogotá (Colombia) exert price discrimination based on buyers' attributes, such as gender and nationality, and based on product characteristics, such as the increasing marginal valuation of items needed to complete a collection. We exploited the seasonal demand for album stickers related to the FIFA World Cup Russia 2018. In our within-subjects design, experimenters carried out in-person audits and quoted a pre-determined list of missing stickers. They interacted with 59 sticker vendors located in five geographic clusters and collected 287 vendor-buyer interactions. We find that prices quoted to foreign buyers are higher than prices quoted to Colombian buyers. By contrast, we do neither find evidence supporting direct genderbased discrimination, nor that vendors charge a higher price per sticker when the list of missing stickers is shorter. We complement the study with a qualitative analysis based on interviews that reveal vendors' pricing strategies, their awareness of price discrimination, and the trade of counterfeits. The qualitative results suggest that price discrimination appears to be unconscious.
\end{abstract}

Keywords: Colombia, Dual labor markets, Football, Latin america, Sports, Street vendors

JEL Classification: C93, J46

\section{Introduction}

The coexistence of formal and informal labor markets is prevalent in low and middle-income countries. In particular, street vending accounts for a significant part of their informal labor sector since it is a major source of employment and income in the main cities. Some street vendors sell the same products year-round, while others invest in seasonal products associated to festivities (e.g., Christmas and Halloween) and sports competitions. Selling this type of merchandise potentially comes with greater returns, but it is also tightly connected to higher economic risks. Once the season is over, vendors have to drastically reduce prices to clear stocks or store them for extended periods, which implies additional costs.

\footnotetext{
*Correspondence: cesar.mantilla@urosario.edu.co

2 Department of Economics, Universidad del Rosario, Bogotá, Colombia Full list of author information is available at the end of the article
}

For a season related to a sports competition, such as the FIFA World Cup, which we explore in this study, vendors prefer to have an accelerated turnover of merchandise instead of storing it, since it is a very costly option. Therefore, in the absence of posted prices in informal markets, we explore whether price discrimination appears as a possible mechanism, either conscious or unconscious, employed by street vendors to quickly recover their investments.

We explore price discrimination in the market of stickers for the FIFA World Cup's album. The tradition of completing this collection has persisted over decades in Colombia, despite the arrival of digital information to keep track of competitors (teams and players) in the World Cup. Among the different seasonal products associated with the World Cup, such as jerseys and flags, we opted to use stickers since they provide two advantages. First, we can test different discriminatory strategies 
since we are able to manipulate the stickers' salience individually. Second, the buyer can credibly signal a low likelihood of future interactions because buyers mostly recur to street vendors when opportunities to trade with other collectors have been exhausted, and the purchase of sealed packets of stickers is likely to bring only duplicates. That is, buyers mostly interact with street vendors to obtain the last missing stickers in the collection. This last feature allows us to minimize reputational concerns related to the intention of suppliers to offer lower prices to ensure future sales.

We conduct two studies to explore three potential sources of discrimination. In the first study, we evaluate two sources of discrimination that might be inferred directly from the buyer's appearance and accent. These are gender and nationality. We have four experimenters quoting a list of nine stickers. Two of them are Colombian and two of them are Argentinian, and there are a woman and a man corresponding to each nationality. In the second study, we evaluate the third source of discrimination. It relates to the quoted set of stickers (i.e., the length of the stickers' list). We have four Colombian experimenters. Two of them quote a long list of nine stickers, and two of them quote a short list of only four. There are one woman and one man corresponding to each type of list.

Discrimination based on nationality is worth being explored in this context for two reasons. First, since sports competitions increase national identity salience (Turchin, 2016), it allows to test discrimination based on in-group favoritism and out-group hostility. Discrimination based on group boundaries has been tested in the context of a previous FIFA World Cup in a market for low-cost electronic devices in Brazil (Kim et al. 2018). Second, foreigners might be subject to discrimination based on the sellers' belief that willingness to pay is higher for foreigners than locals. For developing countries with an increasing tourism industry, it is essential to understand whether informal markets, particularly street-vending, are discriminatory against foreigners and thus have reputational consequences for the whole tourism industry.

We are also interested in gender discrimination given the prevalent stereotypes associating masculinity and sports competitions, particularly in Colombia (Csizma et al. 1988; Grabow and Kühl 2019; Oxford and McLachlan 2018). Sellers might assume that women have less experience buying stickers or are less knowledgeable about stickers' prices and, therefore, discriminate accordingly.

The third element useful to analyze price discrimination is the length of the quoted list. Since the vendor knows that the buyer is quoting the few stickers left to complete the collection, she might charge a larger price for the same sticker when it belongs to a shorter list, as if she anticipates a buyer's higher valuation for the last stickers left.

The literature on market discrimination has mainly focused on two types of discrimination. One of them is taste-based discrimination, related to a preferencedriven mechanism (Becker 1957). The other is statistical discrimination, a belief-driven mechanism relying on self-fulfilling stereotypes (Arrow 1973). ${ }^{1}$ Whereas transactions data provide evidence of discrimination in markets associated with labor, health, housing, tourism, and retail sales (Apollo 2014; Balsa and McGuire 2001; Baranzini et al. 2008; Chen et al. 2018; Grytten et al. 2011; Yip and Wong 2014), the controlled environment from experiments has been useful for pointing out more specific discrimination mechanisms (Ayres and Siegelman 1995; Auspurg et al. 2017; Baert and De Pauw 2014; Baldini and Federici 2011; Castillo et al. 2013; Flage 2018).

Conducting an experiment involves an implicit tradeoff between control and external validity. On the one hand, an experiment closer to the laboratory setting provides greater control, making it easier to test specific mechanisms related to discrimination. On the other hand, natural experiments emphasize realism while holding sufficient control to detect discrimination patterns (Charness and Kuhn 2011; List and Rasul 2011). Correspondence studies, within the family of natural experiments, aim to compare labor outcomes between testers ("confederates" or "auditors") that, by assumption, differ only in the characteristic of interest for the analysis of discrimination, which is typically gender (Bertrand and Mullainathan 2004; Azmat and Petrongolo 2014).

The audit study technique employed in this paper is methodologically close to correspondence studies, and it is based on controlling the characteristics of the testers on one side of the market. When interacting with the other side of the market, it aims to match most of the attributes between testers except the one of interest for detecting discrimination. In correspondence studies, the analysis focuses on the job-offer stage and may include prices (List 2004) and financial or medical advice (Mullainathan et al. 2012; Currie et al. 2011). In our audit, there is a broader set of outcomes. In the experiment, testers act as potential buyers and quote a set of predefined stickers, while street vendors provide prices in their natural environment (remaining unaware of the audit).

\footnotetext{
${ }^{1}$ Recent models bring other mechanisms to the discussion, including unintentional (or implicit) discrimination, search frictions in the labor market, and endogenous group formation (Bertrand et al. 2005; Fang and Moro 2011).
} 
We contribute to this literature by conducting an audit experiment in the context of an informal market, where the lack of enforcement on mandatory posted prices increases sellers' discretionary power (Grossman and Honig 2017). We find evidence of price discrimination based on the buyer's nationality: vendors charge on average $4.8 \%$ more per sticker to Argentinians, and the effects are significant for the most expensive and the least expensive ones. Our conjecture for this finding is that expensive stickers have greater price fluctuation, making it easier for vendors to hide their intention to quote higher prices. Regarding the least expensive stickers, some vendors appear to believe that foreigners are less familiar with the low price charged for stickers printed in regular paper (instead of shiny foil). By contrast, we do not find evidence of price discrimination based on buyers' gender, and neither on the length of the quoted sticker list.

We complement this study with a qualitative analysis based on eleven interviews with street vendors. We focus on describing their pricing strategies, their awareness of price discrimination, and their perception (and trade) of counterfeit stickers. The results from the interviews reveal that vendors do not seem to discriminate consciously. Ten out of eleven interviewees state that they do not charge higher prices to foreigners, whereas about half of them admit selling counterfeit stickers. This result weakens the alternative argument that a social desirability bias drives their responses to price discrimination.

\section{Experimental setting}

\subsection{Description of the stickers market}

Street vendors, who represent a significant part of the informal labor force in Bogotá, Colombia, are not marginalized and typically can afford the acquisition of seasonal products (Martínez et al. 2017). During the Football World Cup, these products include jerseys and flags, and stickers sold individually. The sale of individual stickers is popular among street vendors because they are aware of the high costs of completing the collection and the associated willingness to pay for individual stickers from a considerable number of collectors. ${ }^{2}$ Since vendors have high expectations about the World Cup season, they aim to accrue several duplicates of each sticker beforehand to respond to future demand. Vendors usually start opening boxes as soon as the producer releases stickers. That

\footnotetext{
${ }^{2}$ To give an idea on the high valuation of stickers, the 2018 census on inventory reduction and theft prevention (Censo Nacional de Mermas y Prevención de Pérdidas) revealed that sticker packets were the fifth most stolen item from supermarket chains in the whole year (https://perma.cc/KGM4-MHAH), after canned food products, soft-drinks, candies, and toiletries.
}

is, two to three months in advance of the season's high peak. ${ }^{3}$

In 2018, Completing the collection of 670 stickers cost at least $36 \%$ of the monthly minimum wage in Colombia. ${ }^{4}$ Hence, collectors tend to be located in the city's economic centers and high socio-economic residential areas. Vendors react accordingly and are located in areas with a large influx of office workers, forming clusters of vendors, and in the surroundings of stores of a high-end supermarket chain.

Depending on their budget and time constraints, collectors recur to different strategies when buying sealed packets becomes too expensive due to the frequency of duplicates. One alternative is exchanging stickers at parks or malls, where gatherings coordinated via social media occur. However, they can be time-consuming when the stock of duplicates is not very large. Another alternative for collectors is to interact directly with the vendors. The advantage is that they tend to have a much larger set of stickers to sell (and sometimes trade, although in much more favorable exchange terms for vendors). Therefore, collectors whose budget constraints are looser prefer this strategy.

The price charged on the streets for stickers printed in regular paper (players, pictures of teams, and stadiums) dwells between 1.25 and 2 times the sticker's unit cost in a packet. By contrast, special stickers printed in shiny foil tend to have a much larger price. For the 2018 World Cup, the fifty shiny foil emblems were scarce. Consequently, the price charged by sticker vendors reached between 15 and 50 times the sticker's unit cost in a packet. An alternative strategy was to buy the last missing stickers directly from the manufacturer. However, the stickers that could be purchased under this strategy became unavailable in Colombia one month before the World Cup kick-off (three weeks before our data collection process). ${ }^{5}$ As in many other street-vending activities, sticker vendors are used to bargaining prices with potential customers and have fast interactions that do not lead to a transaction in a considerable number of cases.

\footnotetext{
${ }^{3}$ While the collection only includes 670 stickers, the stock of some vendors reached about 10,000 stickers.

${ }^{4}$ A collector would need to buy 134 packets containing five stickers each, for a total price of 281,400 COP. The monthly minimum wage for 2018 was 781,242 COP. This amount is a lower bound for the cost, under the implausible assumption that the collector would trade any duplicate she obtains. At the time of the experiment, \$1 US Dollar was equivalent to (approximately) 2,900 COP.

${ }^{5}$ A Colombian newspaper issued an article entitled "Panini will no longer ship stickers for the Russia's World Cup album" (https://perma.cc/X34BDHGE). Unlike in the European Union and the United States, collectors cannot directly purchase the complete sticker collection from the official distributor's website.
} 


\subsection{Field site and vendors' selection}

We exploit the seasonal demand for album stickers of the Football World Cup 2018. Six experimenters acted as potential buyers and approached fifty-nine street vendors. We define as vendor any subject, or group of subjects, who sell stickers in a fixed or mobile stall. Regardless of the type of stall, vendors' locations are fixed. Hence, two or more subjects who share a stall are treated as a unique vendor. In consequence, it is possible that two different buyers obtained the prices from the same vendor ID but interacted with different subjects.

The vendors included in our sample were located in five different clusters along the Eastern side of the city, between Street 13th (downtown) and Street 147th. These clusters coincide with centers of economic activity or residential areas of medium-high and high socio-economic status. Other areas of the city were not sampled because sticker vendors were scarce and sparsely distributed. The week before the data collection, two members of the research team mapped the locations of seventy-six street vendors across the five geographic clusters and took pictures of their stalls.

Based on the initial mapping of vendors, we defined as an inclusion criterion that neighboring vendors must be at least two meters away from each other (i.e., we chose them "randomly," conditional on being at least at a $2 \mathrm{~m}$ distance). We excluded from the sample eighteen vendors that were too close to each other. Our final sample includes fifty-nine (78\%) of the initially mapped vendors. Figure 2 shows a detailed description of the vendors' location (see Appendix 1). We have substantial variation in the inclusion rates across clusters. Whereas in the two south-most clusters, the inclusion rate goes above $91 \%$, in the other three clusters, this rate dwells between 53 and $72 \%$. The inclusion rate is particularly low in the cluster of Street 147th, where sticker vendors rent temporary tents located very close to each other (there are fourteen stalls in 120 linear meters). In our two studies, the interactions with street vendors took place between (Tuesday) June 5 th and (Friday) June 8 th, one week before the kickoff of the 2018 World Cup. We conducted the experiment within four days, on the same week, to minimize substantial variations in the vendors' stock of stickers. At most, two buyers were on the field quoting prices on any particular day. They started to quote lists as early as 9:00 a.m. and finished as late as 7:30 p.m. ${ }^{6}$ One of them visited the vendor clusters from South to North of Bogotá, and the other buyer did this process in the opposite direction.

\footnotetext{
${ }^{6}$ One week before conducting the experiment, two research team members randomly asked some vendors their usual schedule in each of the sample zones. Given this information, we could guarantee that most vendors would be present when experimenters quoted prices the following week.
}

We avoided buyers' overlap in the same cluster by delaying the data collection from one of the experimenters. Table 6 (see Appendix 1) details the list of days in which each experimenter quoted the prices.

\subsection{Execution of the audits}

Members from the research team collected the quoted prices in pairs. One of the team members who were initially in charge of mapping vendors' locations always accompanied the buyer. In this way, the companion team member could verify that the buyer was approaching the right vendor. Moreover, we only made contact with the vendor when there were no potential buyers around. The buyer approached the vendor and asked for a list of stickers' prices, while the companion waited at a prudent distance. The opening line of the script, ${ }^{7}$ leading to the vendor-buyer interaction, says:

"My husband/wife and I are looking for the last stickers to complete our kid's PANINI album. He/She is also looking for the stickers right now, so for the moment, I am only quoting. Do you complete lists (of missing stickers)?”

Given the nature of street-vending in Colombia, quoting prices without committing to a purchase is an everyday interaction. Nonetheless, it is important to discuss two trade-offs created by this script. First, it increases the internal validity. However, it comes at the expense of a greater likelihood that sellers could detect that they were part of an audit. Second, quoting rather than purchasing stickers is useful to leave unaltered the stock of specific stickers. Nevertheless, neighboring vendors observing a failed transaction might update their perception of the buyer's bargaining skills. We argue that the two caveats of using the script are dampened by the exclusion rule used to sample vendors and by leaving sufficient time between interactions from the same vendor with two different research team members.

Mentioning that the stickers are for the buyer's kid, and that these are being simultaneously quoted for both parents, helps reducing the commitment for a purchase. Moreover, mentioning the kid on the script aims to prevent vendors from inferring that men were quoting the stickers for themselves, whereas women were doing this task for someone else. We aim at blocking the latter possibility, which might be interpreted as a confounder of gender-based discrimination with what Balafoutas et al. (2015) define as "second-order moral hazard." That is, the tendency of the supply side (i.e., sticker vendors) to anticipate the moral hazard on the demand side (i.e.,

\footnotetext{
${ }^{7}$ See Appendix 2 to read the full script.
} 
women quoting stickers for a third party), which results in changes in the price associated with the inference of whom is the final payer. In our design, mentioning the kid makes more likely that male and female buyers are assumed as final payers of the stickers.

Buyers dressed similarly, with semi-formal clothes to represent that they were in their late twenties or midthirties, close to their actual age, ranging from 24 to 40 years old. Once the vendor confirms that she/he sells individual stickers, we start reading aloud a handwritten list of stickers (the set included on the lists is explained in the next section). The buyer registered every quoted price of the list, element by element. In case that the vendor did not have the sticker, we asked for the price she would charge to find it. In case the vendor said that she could not find the sticker, we asked for the price she had previously charged for it in past transactions. This procedure allowed us to increase the chances of obtaining information from every quoted sticker, even if it was not available at the time.

One might think that this procedure makes the audit seem "artificial," as if the buyer put more emphasis on learning about the prices rather than looking for a transaction. We provide two reasons why we consider this is not a major concern. First, from the beginning of the interaction, the buyers mentioned that they were, for the moment, only quoting the stickers. Consequently, since any transaction would occur another day, asking for the price of currently unavailable stickers would make sense if they could be obtained on a future date. Second, although there are 670 stickers, the total number of price categories is much lower (see Sect. 2.4). ${ }^{8}$ Therefore, asking about the price of a currently unavailable sticker would have been equivalent to quote another sticker from the same price category (and the latter type of question would have seemed more artificial).

An additional concern about this procedure, in which we quote unavailable stickers, is that prices might include search costs. Although this is a valid concern, we observe that the likelihood that vendors did not have the requested sticker but mentioned a price for getting it was low. Table 7 (see Appendix 1) reveals that, on average, it only occurred in $4.35 \%$ of the vendor-buyer interactions (and for $2 \%$ of all the potential quoted stickers). ${ }^{9}$ Moreover, we believe that search costs were low for two reasons.

\footnotetext{
${ }^{8}$ Vendors recognize four categories of stickers: front page emblems, "Legends," team emblems, and regular stickers (stadiums, teams' picture, and players).

9 The likelihood that vendors did not have the requested sticker and did not mention a price for getting it was also low. Table 7 shows that, on average, it only occurred in $4.17 \%$ of the vendor-buyer interactions (and for $2.1 \%$ of the total number of quoted stickers).
}

First, $60 \%$ of our sample of vendors are close enough to each other, and therefore looking for these stickers has a low transaction cost. Second, vendors typically do not get involved in monetary transactions between them. Instead, the vendor borrows stickers from another vendor to secure the transaction with the buyer, and then gives back the same sticker, or an equivalent one to the lender. A broad definition of equivalence is defined by the four categories mentioned before: front page emblems, "Legends," team emblems, and regular stickers. These "equivalences" also make more plausible the assumption that "mental search costs," defined as the cognitive costs of recalling the price of stickers previously sold, are not very high either.

The buyer carried a handwritten list and a printed form. Both included the list of stickers. The latter added information buyers had to collect prior to the interaction: vendor's gender, an assessment of her/his age, whether she/he sells other products (related or not to the World Cup), type of stall, date and time of the interaction (plus some empty lines for taking relevant notes regarding the interaction).

Buyers used the handwritten list during the interaction, so if the vendor wanted to grab the list, it would not have revealed any additional information about the experiment. Different members of the research team made the handwritten lists. After finishing the interaction with the vendor, the buyers walked away, hid from the vendor's sight, and filled out the printed form.

\subsection{Selection of stickers}

The FIFA World Cup album's stickers can be divided into two main groups: those printed in shiny foil and those printed in regular paper. The latter corresponds to $92.5 \%$ $(620 / 670)$ of the entire collection and includes photographs from players, teams, and stadiums. Most collectors exchange on a 1-to-1 basis these "regular" stickers, and most vendors (69\%) charge around 1.0 and 2.5 times the unit cost (i.e., the cost of the packet divided by five, the number of stickers in the packet) for them. Tables 1 and 2 display the list of selected stickers for each study. We included three "regular" stickers (a stadium, a team, and a player) in the long lists. The purpose of including these stickers was twofold: (i) make more salient the difference between the long list ( 9 stickers) and the short list (4 stickers) in Study 2, without considerably affecting the difference in total prices, and (ii) make more engaging and realistic the long list for sticker vendors.

The fifty shiny foil stickers have three main categories and are significantly more expensive than regular stickers. The eight stickers on the front page of the album are the first category. These stickers are related to the World Cup (e.g., logo, poster, mascot, ball). The second category 
Table 1 Study 1: Composition of stickers' lists and variation in buyers' attributes

\begin{tabular}{|c|c|c|c|c|}
\hline \\
\hline \multicolumn{5}{|l|}{$\begin{array}{l}\text { Experimenter Information } \\
\text { ID }\end{array}$} \\
\hline Nationality & Argentinian & Argentinian & Colombian & Colombian \\
\hline Gender & Female & Male & Female & Male \\
\hline List quoted & Long & Long & Long & Long \\
\hline Sticker type & & $\begin{array}{l}\text { Stickers quoted by each } \\
\text { experimenter }\end{array}$ & & \\
\hline Local team emblem & Colombia & Colombia & Colombia & Colombia \\
\hline Front page emblem 1 & FIFA World Cup Trophy & FIFA World Cup Trophy & FIFA World Cup Trophy & FIFA World Cup Trophy \\
\hline Front page emblem 2 & Ball Telstar & Ball Telstar & Ball Telstar & Ball Telstar \\
\hline World Champion sticker & Maradona (ARG) & Maradona (ARG) & Maradona (ARG) & Maradona (ARG) \\
\hline Team emblem tier 1 & Argentina & Argentina & Argentina & Argentina \\
\hline Team emblem tier 2 & Uruguay & Mexico & Peru & Uruguay \\
\hline Stadium & Samara & St. Petersburg & Spartak & Nizhny Novgorod \\
\hline Team & Iceland & Denmark & Denmark & Iceland \\
\hline Player & Busquets (ESP) & Lallana (ENG) & Lallana (ENG) & Busquets (ESP) \\
\hline $\begin{array}{l}\text { Total Number of stickers quoted } \\
\text { on the list }\end{array}$ & 9 & 9 & 9 & 9 \\
\hline
\end{tabular}

$\S$ Every experimenter quoted one sticker from each row. Most of the stickers are printed on shiny foil, except the stadiums, teams, and players, printed on regular paper. Although we cannot have a formal test to check that the stickers quoted in each category by different buyers are the same, we know that sellers, in general, assign prices based on a limited number of sticker types. Vendors usually do this because having prices for each of the 670 stickers is an enormous cognitive cost for them, and it also increases the menu costs. Additionally, by the very nature of street sales, these are fast transactions, and sellers usually mention prices quickly when one asks for a quotation.

Table 2 Study 2: Composition of stickers' lists and variation in list's length

\begin{tabular}{|c|c|c|c|c|}
\hline \\
\hline \multicolumn{5}{|l|}{$\begin{array}{l}\text { Experimenter Information } \\
\text { ID }\end{array}$} \\
\hline Nationality & Colombian & Colombian & Colombian & Colombian \\
\hline Gender & Female & Male & Female & Male \\
\hline List quoted & Long & Long & Short & Short \\
\hline Sticker type & & $\begin{array}{l}\text { Stickers quoted by each } \\
\text { experimenter }\end{array}$ & & \\
\hline Local Team Emblem & Colombia & Colombia & Colombia & Colombia \\
\hline Front page Emblem 1 & FIFA World Cup Trophy & FIFA World Cup Trophy & FIFA World Cup Trophy & FIFA World Cup Trophy \\
\hline Front page Emblem 2 & Ball Telstar & Ball Telstar & Panini Logo & Fair Play Logo \\
\hline Legend & Maradona (ARG) & Maradona (ARG) & x & x \\
\hline Team Emblem Tier 1 & Argentina & Argentina & Brazil & Germany \\
\hline Team Emblem Tier 2 & Peru & Uruguay & x & x \\
\hline Stadium & Spartak & Nizhny Novgorod & $x$ & $x$ \\
\hline Team & Denmark & Iceland & $x$ & $x$ \\
\hline Player & Lallana (ENG) & Busquets (ESP) & $x$ & $x$ \\
\hline $\begin{array}{l}\text { Total Number of stickers quoted } \\
\text { on the list }\end{array}$ & 9 & 9 & 4 & 4 \\
\hline
\end{tabular}

$\S$ Every experimenter quoted one sticker from each row. The "x" denotes that this sticker was not quoted in the Short List treatment. The quoted stickers are printed on shiny foil, except the stadiums, teams, and players, which are printed on regular paper

comprises thirty-two team emblems, one per each participating team. Finally, ten stickers presented on the last page of the album form the last category. These stickers are called "Legends" and correspond to the existing World Champions and top-scorers. We learned from the quoted prices that the team emblems are the least expensive among these three categories. An exception is Colombia's team emblem. Given that the audit was conducted in Bogotá, vendors tend to charge the highest price for this sticker. Since the shiny foil stickers are 
more expensive than the regular ones, in particular those on the front page, plus Colombia's emblem, and the "Legend," they open a broader space for price discrimination, either gender-based or nationality-based.

The remaining six stickers included in Study 1 are printed in shiny foil. Two of them are stickers from the front page, one is a "Legend", and the other three are team emblems. Given the buyers' nationality, we decided to incorporate Colombia's emblem and Argentina's emblem (team in Tier 1). The third emblem is a Latin American team in Tier 2 (either Mexico, Peru, or Uruguay), which serves as a baseline cost for team emblems.

In Study 2, our primary purpose is to detect price differences per sticker when they belong to a long or a short list. In the audit experiment, the long list is identical to the one from Study 1 (indeed, observations from two buyers overlap between studies). For the short list, experimenters quoted two stickers from the front page, Colombia's emblem, and a Tier 1 emblem: Brazil or Germany. In this sense, the short list included three stickers where price discrimination might be more pronounced, plus the Tier 1 team's emblem as a baseline within the short list.

\subsection{Study 1: Price discrimination based on buyers' attributes}

Four experimenters were acting as (potential) buyers. They differed in nationality (two Colombians and two Argentinians) and gender (two males and two females). We expected that vendors could infer that foreigners were Argentinians due to their pronounced accent; and due to some slight variations in the script. For example, the script for the Argentinian buyers included the underlined words:

I am missing one legend, number 664, the one with the best player in history: Maradona. The guy is a genius! How much is it?

Although these additional words make the script slightly different for Argentinians, we argue that the benefit (i.e., remarking the foreigner buyer's nationality) exceeds the cost (i.e., the risk that these words, and not nationality per se, drive the price differences).

We exploit those differences to detect price variations between nationalities and between genders. Table 1 reports the list of stickers that experimenters quoted in Study 1 . We present the nine quoted stickers in descending order according to their average quoted price.

We acknowledge the limits of our study's "experimental" character since neither gender nor nationality of the buyers were randomly assigned (Siegelman and Heckman 1993). Nonetheless, our design aims to overcome this limitation by having multiple interactions for each of the audited vendors, allowing us to introduce seller's fixed effects into the econometric specification. With this caution in mind, we can check gender differences by comparing prices given to the experimenters with IDs 1 and $3 v s .2$ and 4; and we can check differences by nationalities by comparing prices given to experimenters with IDs 1 and 2 vs. 3 and 4 (see Table 1).

\subsection{Study 2: Price discrimination based on sticker list's attributes}

The purpose of collectors of the FIFA World Cup album is to complete the whole set of stickers. We argue that, when there are few stickers left to complete the collection, it is plausible that each additional sticker's marginal value is increasing. In other words, the sticker is valuable per se, and because collectors derive utility from getting closer to the completion of the set. Thus, we can test whether street vendors adopt a sophisticated pattern of price discrimination, in which they extract a signal of the buyers' increasing valuation of the missing stickers based on the length of the list. We conducted a second experiment in which we hold constant the buyers' nationality (i.e., all of them are Colombian) to focus on the length of the quoted list. We devised a short list of stickers, comparable to a subset of what we refer to as the long list employed in Study 1.

Table 2 compares the long list for experimenters with IDs 3 and 4 (i.e., the same data collected in Study 1) with the short list for the new experimenters with IDs 5 and 6 . To test whether the vendors charge more per sticker when the inferred marginal valuation of stickers is higher, we compare the quoted prices on the Long List treatment (IDs 3 and 4) to the quoted prices on the Short List treatment (IDs 5 and 6).

\section{Data}

We collected information on interactions between 59 street vendors and 6 experimenters or buyers. We thus have a total of $(59 \times 6) 354$ potential vendor-buyer interactions. We gathered 287 (81\%) of such interactions, 199 for the Long List, in which we had four buyers; and 88 for the Short List, in which we had two buyers. The missing interactions correspond to cases where the experimenter could not find a specific vendor. Figure 3 in Appendix 1 maps the interactions of each buyer with vendors. The average number of interactions per vendor was 4.86 , and the median was 5 . Forty-one percent of the vendors interacted with all the experimenters, whereas fourteen percent of the vendors interacted with less than four experimenters. Taking "sticker $\times$ interaction" as the unit of observation, we have a total of 1712 observations in the Long List treatment corresponding to four experimenters and 302 in the Short List treatment corresponding 
to two experimenters. Note that 1712 is lower than the $(199 \times 9=) 1791$ potential observations in the Long List, and 302 is lower than the $(88 \times 4=) 352$ potential observations in the Short List. The reason is that some vendors did not have some stickers or refused to quote the prices individually and instead provided the price of the entire list. $^{10}$

Regarding vendors' characteristics, we find that $42 \%$ were in their stall without any companion. According to our measure of perceived age, $61 \%$ of sellers were 35 years old or younger. Concerning vendors' location, we find that $43 \%$ of vendors are far from any other vendor (more than $50 \mathrm{~m}$ away), $44 \%$ are at a prudent distance from at least another vendor (between 10 and $50 \mathrm{~m}$ away), and the remaining $14 \%$ are all located very close to each other (between 2 and $10 \mathrm{~m}$ away). ${ }^{11}$ As mentioned before, we excluded from the sample any vendor at a closer distance. The right panel of Figure 2 in Appendix 1 shows each vendors' location within their geographic cluster. Vendors were particularly close to each other in the clusters located in Street 85th and Street 147th. For the statistical analysis, we defined only two categories of distance to other vendors: being far from (i.e., more than $50 \mathrm{~m}$ away) or close to (i.e., less than $50 \mathrm{~m}$ away) any other vendor.

Since most buyers quoted the price of stickers with every vendor, we analyze the interactions as a withinsubjects design. Nonetheless, we check whether vendors' characteristics are balanced across the experimenters' features of interest in Study 1, and across types of lists and experimenters' features in Study 2, for two reasons. First, we have some degree of attrition because the experimenters could not find all vendors. Second, according to our assignment of vendor ID, the experimenters might have interacted with different people located in the same stall.

Table 8 in Appendix 1 shows the coefficients of four linear probability models in which we take as covariates the vendors' gender and (perceived) age, whether the vendor was isolated, and the journey (morning or afternoon). None of the covariates are correlated with the buyer's nationality. However, in Study 1, vendors perceived as older are more likely to interact with male (instead of female) buyers. In Study 2, male vendors in the Short List

\footnotetext{
${ }^{10}$ Three vendors out of forty-eight gave the total price for the list of nine stickers to the Colombian buyer instead of quoting the prices individually. Seven vendors out of forty gave the total price to the male buyer for the list of four stickers and did not mention individual prices. In the case of the female buyer quoting the short list, five out of forty-eight vendors preferred to give the total price for the four stickers instead of mentioning prices individually.

11 The statistics presented in the text correspond to the average for the six experimenters. Since it is possible that buyers interacted with different vendors at the same stall, we first compute these demographic statistics per experimenter and then we average the reported percentages.
}

tend to have more interactions during the afternoon (i.e., after 12:00 m) compared to female vendors. We control for these variables in our regression analysis.

\section{Results}

\subsection{Study 1: Econometric results for discrimination based on buyer's attributes}

We estimate a simple linear regression model with robust standard errors and vendor fixed effects to test whether street vendors quote different prices based on the buyer's nationality or gender. The estimated model is given by:

$$
\text { Price }_{s i j}=\beta_{1} \text { Foreign }_{j}+\beta_{2} \text { Male }_{j}+X_{i}^{\prime} \alpha+T_{s i j}^{\prime} \delta+\epsilon_{s i j}
$$

The dependent variable is the price of sticker $s$ quoted by vendor $i$ to buyer $j$, expressed in thousands of Colombian pesos $[\mathrm{kCOP}]$. The indicator Foreign equals one if the buyer is Argentinian and equals zero if the buyer is Colombian. Similarly, Male equals one if the buyer is a man and equals zero otherwise. In this equation, $X_{i}$ is a vector of vendors' characteristics, including age, gender, geographic location (cluster), and the presence of neighboring sticker vendors. The vector $T_{i s j}$ includes sticker fixed effects, a categorical variable for the day of the week in which the interactions took place, and a dummy variable for whether the interactions occurred in the morning or in the afternoon.

Results from Table 3 reveal that prices per sticker quoted to Argentinians are 208 COP higher than those quoted to Colombians (about $4.8 \%$ higher with respect to the mean price of the 1712 stickers in the regression). However, we do not observe a systematic difference in prices between male and female buyers. Although male buyers are quoted 290 COP more per sticker than female buyers, standard errors are slightly larger than the coefficients, and therefore we cannot reject the absence of price discrimination based on the buyer's gender. Models 1 and 2 show that the results are similar using classical or robust standard errors. Given the small number of experimenters acting as buyers, we cannot cluster the standard errors at the "pseudo-randomization" level.

The econometric model includes seller fixed effects. This specification allows us to exploit the within-subject nature of our sampling strategy. In other words, the observed differences in quoted prices based on buyers' attributes come from (a subset of) sellers quoting different prices to local and foreign buyers. In this case, the difference we obtain is more robust than what would have been obtained by comparing quoted prices given by sellers that interacted with local buyers to prices given by (comparable) sellers that interacted with foreign buyers (between-subjects design). Figure 1 depicts some coefficients of interest from Eq. 1. Panel A shows that vendors quote a higher price for shiny foil stickers, particularly for stickers on the album's front page and 
Table 3 Effect of buyer's attributes (nationality and gender) on street vendors' price quotations

\begin{tabular}{|c|c|c|c|c|}
\hline Variables & (1) Price $[\mathrm{kCOP}]$ & & (2) Price $[k C O P]$ & \\
\hline Foreigner & $0.208^{*}$ & $(0.113)$ & $0.208^{*}$ & $(0.120)$ \\
\hline Male Buyer & 0.290 & $(0.303)$ & 0.290 & $(0.369)$ \\
\hline Constant & -0.168 & $(0.326)$ & -0.168 & $(0.284)$ \\
\hline R-squared & 0.799 & & 0.799 & \\
\hline $\begin{array}{c}\text { Controls and } \\
\text { Vendor FE }\end{array}$ & Yes & & Yes & \\
\hline Errors & Standard & & Robust & \\
\hline Vendors & 59 & & 59 & \\
\hline $\begin{array}{l}\text { Number of } \\
\text { observa- } \\
\text { tions }\end{array}$ & 1712 & & 1712 & \\
\hline
\end{tabular}

One of the advantages of creating a list with multiple items to quote is the opportunity to explore more sophisticated patterns of price discrimination. Since we verified the existence of price variation across sticker types (see Panel A in Fig. 1), we now conduct the regression analysis separately for each sticker on the list.

Table 4 reveals the results for the price quoted for each sticker. Additionally, Column 1 shows the price quoted for the full list. This result confirms that vendors charge larger prices to Argentinians than to Colombians (on average, 2,438 COP more). Nonetheless, this pattern is not uniform across stickers: the second most expensive sticker (i.e., the FIFA Trophy), and the two cheapest stickers on the list, drive the higher prices quoted to foreigners. The coefficients for the two other most expensive stickers, Colombia's emblem and the Official ball-Telstar, show a pattern similar to the FIFA Trophy, though they are less precisely estimated.

We offer a conjecture for this pattern, in which Argen-

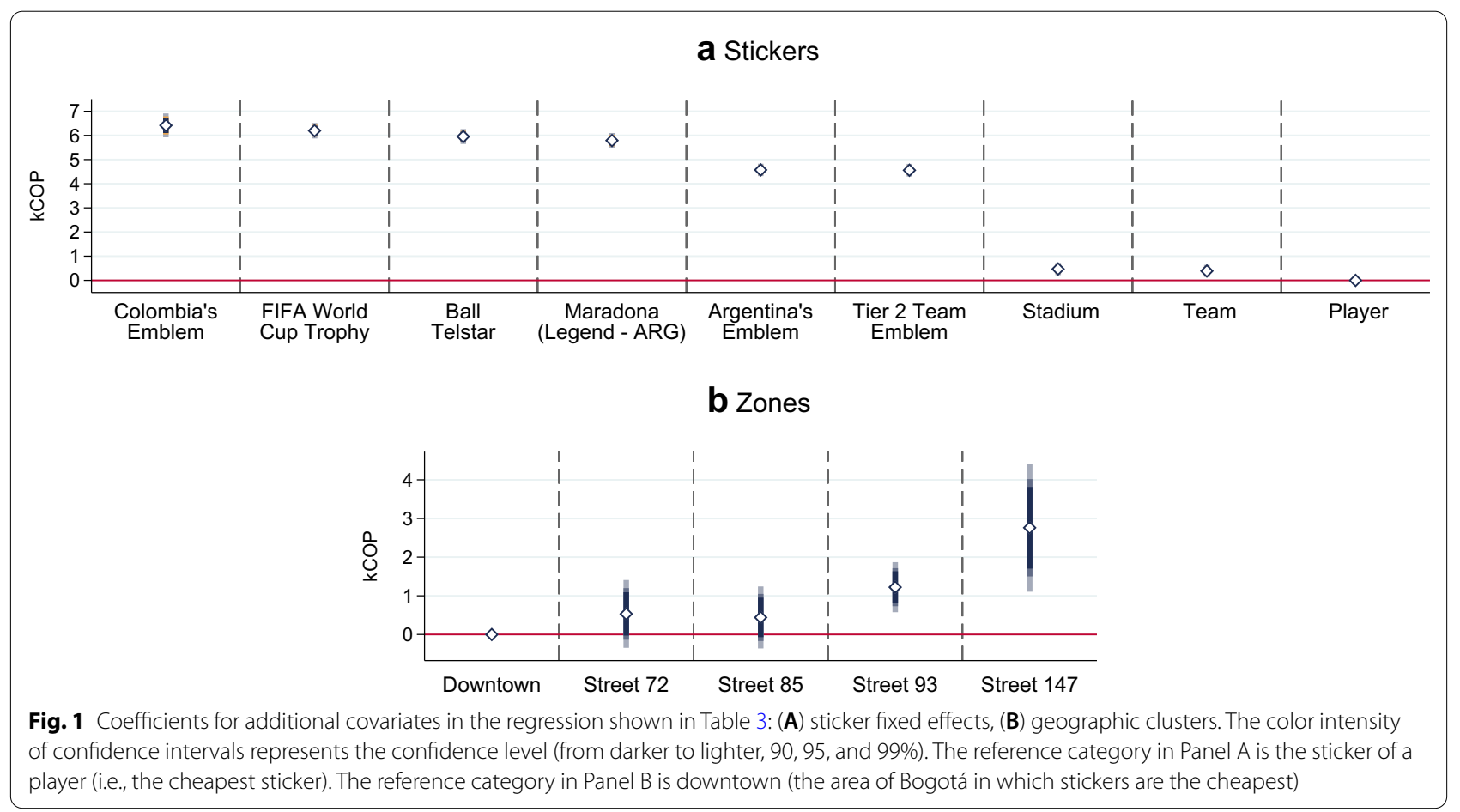

Colombia's emblem. Panel B reveals that stickers' price differs between spatial clusters, increasing as we move to the Northern side of Bogotá. ${ }^{12}$

\footnotetext{
${ }^{12}$ An explanation for the considerably larger price in the farthest cluster (Street 147th) is that sticker vendors rent temporary tents located in a small mall's borders at a significant price (about 1.5 monthly minimum wages). It leads to a very high concentration of vendors (fourteen in 120 linear meters) that, despite their spatial closeness, manage to keep the city' highest prices. However, given their spatial proximity and their long-lasting reputation of selling stickers in every World Cup, it is also possible that vendors in this area are more likely to collude.
}

tinians are simultaneously charged more for the most and the least expensive stickers. On the one hand, vendors have more discretionary power to raise prices of the most expensive stickers, arguing that they are in high demand. One could interpret this result based on the heterogeneity in price discrimination detection (Grossman and Honig 2017). This pattern is not observed for other shiny foil stickers with a small variation in their price, such as team emblems. On the other hand, for teams and players, 


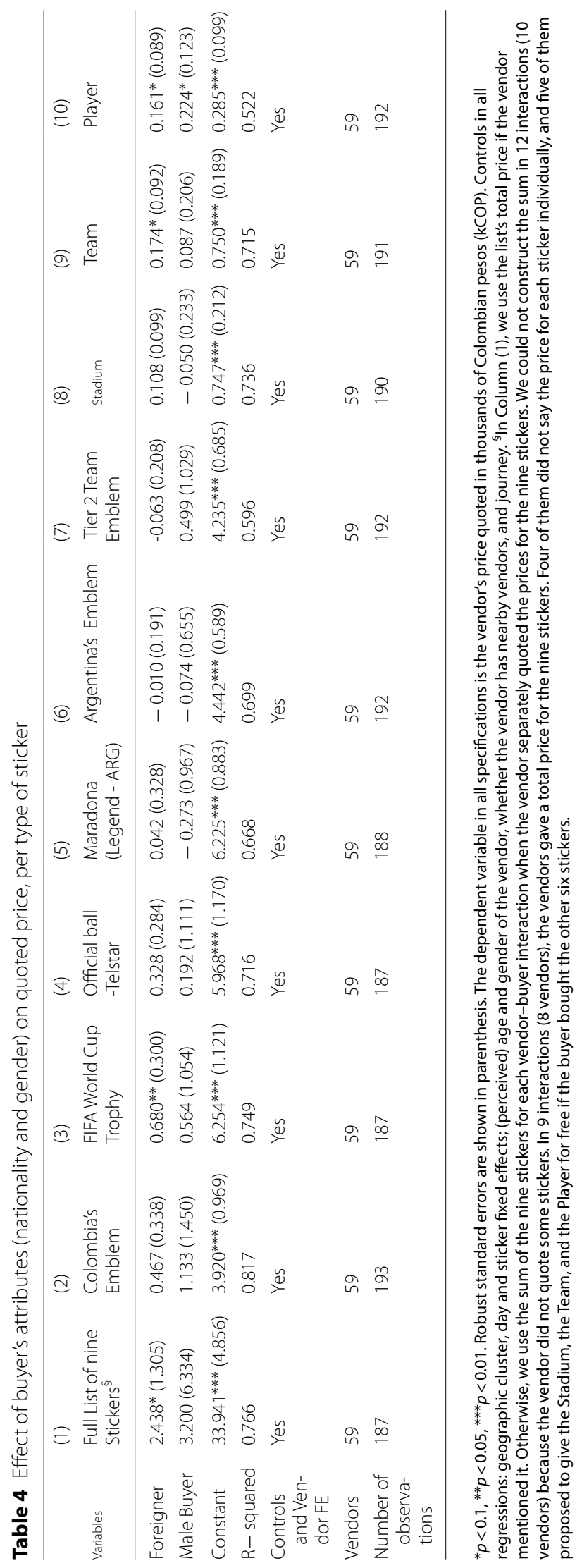


the least expensive stickers on the list, the modal prices are 1000 and 500 COP, respectively. That is, they are between five and ten times cheaper than the least expensive shiny foil stickers. Figure 4 reveals that foreigners are more likely to be charged prices two or three times larger than the modal price for these regular stickers. Another mechanism that might be at play for the least expensive stickers emerges from the fact that regular stickers are sometimes offered "as a gift" when purchasing the shiny foil stickers. However, we do not find evidence that these gifts are more likely to be offered to Colombians.

Regarding the analysis of gender differences, Table 4 provides additional, suggestive evidence that male buyers do not appear to receive systematically different quoted prices compared to female buyers. Nonetheless, these results must be taken with caution since the sample size sharply decreases at the sticker level. Similar to the discrimination against Argentinians, it might be the case that men are also charged higher amounts for the most expensive stickers, particularly for the Colombian emblem.

As an additional check, we add to the econometric model the interaction between the buyer's and the vendor's gender. Table 9 reveals that gender interaction variables are not statistically significant. Therefore, even if we consider more specific mechanisms in which male vendors might discriminate against male buyers but not against female buyers or vice versa, we do not detect price differences based on gender.

\subsection{Study 2: Econometric results for discrimination based on list's attributes}

We discussed earlier that stickers might have an increasing marginal utility when the buyer's purpose is to complete the stickers collection. Vendors could then anticipate a greater willingness to pay for the same sticker from a buyer revealing a short list of missing stickers, with respect to a buyer revealing a long list of missing stickers. We conduct a regression similar to Eq. (1), replacing the variable that captures buyer's nationality (since all the experimenters in Study 2 are Colombians) for a variable indicating whether the quotation corresponded to a short or a long list. We focus here on the quoted price for the four stickers listed in Table 2 that are common to both lists: Colombia's emblem, the FIFA World Cup Trophy, an additional shiny foil sticker from the front page (i.e., the Official ball-Telstar, the FIFA Fair Play logo or the Panini Logo) and the emblem from a Tier 1 team (Argentina, Brazil or Germany).

We report the comparison between the Short List and the Long List treatments in Table 5. The first column corresponds to the model pooling all four stickers, whereas the next four columns display the coefficients of interest for each of the listed (and comparable) stickers. We do not find evidence suggesting that vendors charge a larger price for the same sticker when it belongs to a short list compared to when it belongs to a long list. Although the number of observations is smaller in this econometric exercise (the sticker list is shorter and Argentinians were excluded), coefficients for the indicator variable for the Long List variable are very close to zero. In other words, the lack of significance does not reflect a lack of statistical power.

We have two conjectures for the absence of an effect. The first one is that sellers do not exploit the (assumed) higher marginal valuation for fewer missing stickers. The second conjecture is that, although one of the lists is twice as long as the other, both lists could be considered by the vendor to be "short," in absolute terms.

\section{Qualitative results from interviews}

In addition to our audit studies, we conducted eleven interviews with sticker vendors that were part of our original sample. At least two vendors were interviewed per geographic cluster. The purpose was to complement our insights from this market and elicit sellers' perceptions of price discrimination. The interviews were conducted four weeks after the audit experiment. By that time, the knockout-stage of the FIFA World Cup was already taking place, and the sale of stickers was less intense, so it was feasible to ask sellers to participate in our interview. The interviews were conducted on July 2, 2018, an official holiday in Colombia, for the two clusters corresponding to residential areas. We selected this day because there were substantially fewer people, and the probability of the vendor accepting the interview was higher than on a business day. The other three clusters correspond to economic activity centers, and sticker vendors do not work on holidays. Hence, we conducted the interviews the day after. ${ }^{13}$

We opted for conducting eleven interviews due to budget constraints since we offered compensation for the vendors' time. We selected the vendors based on three attributes. First, vendors for whom we had completed the interactions with each experimenter (six in total). The reason was to maximize the chances of finding the selected vendor by the time of the interview. Second, since we had six observations per selected vendor, we aimed at guaranteeing that it was the same person in

\footnotetext{
${ }^{13}$ One final interview was completed ten days later (July 13). We decided to make this last interview to obtain an additional testimonial from the area where vendors were closer to each other but from one of the few isolated vendors in this area.
} 
Table 5 Effect of sticker list's attribute (length) on quoted price, per type of sticker

\begin{tabular}{llllll}
\hline Variables & $\begin{array}{l}\text { (1) Full list of four } \\
\text { stickers }^{5}\end{array}$ & (2) Colombia's Emblem & $\begin{array}{l}\text { (3) Front Page Emblem } \\
1\end{array}$ & $\begin{array}{l}\text { (4) Front Page Emblem } \\
2\end{array}$ & $\begin{array}{l}\text { (5) Tier 1 Team } \\
\text { Emblem }\end{array}$ \\
\hline Long List & $0.056(0.113)$ & $0.095(0.237)$ & $0.021(0.150)$ & $0.046(0.155)$ & $0.014(0.127)$ \\
Male Experimenter & $-0.029(0.122)$ & $0.221(0.247)$ & $-0.204(0.147)$ & $-0.261^{*}(0.150)$ & $0.013(0.126)$ \\
Constant & $4.064^{* * *}(0.438)$ & $3.034^{* * *}(0.714)$ & $4.433^{* * *}(0.458)$ & $4.322^{* * *}(0.424)$ & $3.650^{* * *}(0.431)$ \\
R-squared & 0.553 & 0.803 & 0.838 & 0.811 & 0.709 \\
Controls and Vendor FE & Yes & Yes & Yes & Yes & Yes \\
$\begin{array}{l}\text { Number of observa- } \\
\text { tions }\end{array}$ & 697 & 176 & 172 & 173 & 176 \\
\hline
\end{tabular}

${ }^{*} p<0.1,{ }^{* *} p<0.05,{ }^{* * *} p<0.01$. Robust standard errors are shown in parenthesis. The dependent variable in all specifications is the vendor's price quoted in thousands of Colombian pesos (kCOP). Controls in all regressions: geographic cluster, day and sticker fixed effects; (perceived) age and gender of the vendor, whether the vendor has nearby vendors, and journey. Front Page Emblem 1: FIFA World Cup Trophy. Front Page Emblem 2: Official ball-Telstar, FIFA Fair Play Logo, or Panini Logo. Tier 1 Team Emblem: Argentina, Brazil, or Germany. ${ }^{\S}$ In Column (1), we use the list's total price if the vendor mentioned it. Otherwise, we use the sum of the four stickers for each vendor-buyer interaction when the vendor separately quoted the prices for the four stickers. We could not construct the sum in 3 interactions ( 3 vendors) because the vendor did not quote one of the four stickers. In 24 interactions ( 21 vendors), the vendors gave a total price for the four stickers. Eleven of them did not say the price for each sticker individually.

all the interactions. Third, we guarantee one man and one woman were interviewed in each cluster.

The interviewer approached the vendor and asked if she/he could respond to some non-personal questions that would take between 15 and $20 \mathrm{~min}$. We list the questions in Appendix 1.

A. The interviewer would buy one of the shiny foil stickers for 10,000 COP in appreciation. By the time of the interview, the price of such stickers was about 4,000 to $6,000 \mathrm{COP}$. All the vendors initially approached by the interviewer agreed to participate. We did not mention any relationship between the interview and the audit study, as it may have caused unpleasantness among the interviewees. We requested permission to record the interview, and all of them accepted.

We interviewed five women and six men with the following characteristics. The interviewer perceived eight of them as being older than 35 years. Five of them declared to work in their stall alone, whereas the other six declared to work with at least one more person. In most of the cases, this companion person was not a relative. Working hours from interviewed vendors went from 8 to $12.5 \mathrm{~h}$ a day, with an average of 10.4. Depending on the geographic cluster, they work on weekdays (Downtown and 72nd Street) or the whole week (85th, 93rd, and 147th Street). Some of them claimed that they were working more hours than usual given the World Cup Season. Eight of the interviewees were also dedicated to street vending the rest of the year, and they sell other seasonal products (e.g., Christmas merchandise) or specific products such as flowers, fast food, umbrellas, and used books. Another two vendors who replied to this question worked in tailoring and building maintenance, respectively. The remaining one did not answer. Three vendors declared to contribute to the pension system or health system.

Two interviewees in Street 147th were located in fixed stalls. One paid a monthly rent of approximately $1,200,000$ COP, and the other paid 1,700,000 COP (between 1.5 and 2 monthly minimum wages). The rest of the interviewees had a mobile stall. Although they could change locations within or between days, sticker vendors tend to stay in a fixed spot during the World Cup. All but one of the interviewed vendors has stayed in the same spot since at least the 2010 FIFA World Cup. Despite the Constitutional protection of street vendors, they are sometimes subject to police inspections that might lead to confiscation of their merchandise. In these cases, vendors with mobile stalls locate nearby their usual spot.

\subsection{Pricing strategies}

We identify three different types of strategies based on the responses from eight interviewees, which we define as frequency-based, distributor-based, and imitation. ${ }^{14}$

The most usual strategy is what we define as frequencybased. It consists of opening a vast number of boxes, each containing 104 packets with five stickers each, for a total of 520 stickers per box, and then inferring each sticker's rarity to assign prices based on how scarce they are. The following is an example of a vendor using this strategy:

\section{[Excerpt 1] "Well, I already have experience with the World Cup, right? I open boxes because you must open boxes or master boxes as people say... because}

\footnotetext{
14 The responses of the three remaining vendors cannot be linked to any strategy. These were: "based on the price of the box", "shiny foil stickers cost 4,000 COP, except \#1 that is more costly, and any other sticker costs 300 COP", and "this is my fourth World Cup selling stickers, so based on my experience."
} 
a master box contains 12 boxes. So let's say I open 3 , 4, master boxes. Then, by arranging the stickers by numbers, I deduce the team that comes out the most, the players who come out the most, and the stickers that come out the least. Hence, those that come out the most are the cheapest, and those that come out the least are the most expensive."

When asked about the number of opened boxes, the responses ranged from 24 to 100 . This process gives between 12,500 and 52,000 stickers, which will be sufficient to complete between 18 and 77 collections in the absence of duplicate stickers. The frequency-based strategy requires a substantial investment since each box initially cost them around 180,000 COP. ${ }^{15}$ Opening 24 boxes would cost 4,320,000 COP, more than five times the monthly minimum wage at the time.

The distributor-based strategy consists of following the prices per sticker suggested by their PANINI distributor for most of the stickers. In general, vendors were instructed to charge 300 COP per sticker and comply with most stickers. However, they tended to charge more for the shiny foil stickers and others that they considered rare.

Finally, imitation consists of adjusting to the prices set by other vendors. They gather information on sticker prices by directly asking neighboring vendors. For instance, a vendor said:

[Excerpt 2] "We set prices based on past sales experience and checking with other sellers."

One of the interviewed sellers claimed that sometimes they have to lower prices even if it leads to losses because their neighboring vendors create much competition. More precisely, she says:

[Excerpt 3] "Well, I have tried to change the prices, because at least with the stickers, the shiny ones are the difficult ones and then I am the one that sets the highest prices. The rest of the stickers are cheap because of the price war. It is about the one who sells more... is not the one who earns the most, but the one who sells the most... is the one who wants to fight for a client, the one who gives him/her the lowest price. Also, clients put a price on the merchandise. In other words, you cannot set the price because they already come to impose the prices."

The two vendors following an imitation strategy were located on the cluster in the 147th Street, where vendors' stalls are closer to each other than any other cluster, but

\footnotetext{
${ }^{15}$ The official price per box to the public was 218,400 COP, about $21 \%$ more expensive.
}

average prices are also higher than in the other clusters. It is also worth mentioning that, whereas they perceive the information provided by other vendors as useful, several vendors also claimed that they dislike when buyers tell them that a nearby vendor is selling the same sticker for a lower price. Regardless of whether the prices provided by buyers were truthful or were part of a bargaining strategy, vendors appeared to dismiss this information.

\subsection{Awareness of price discrimination}

We included four questions regarding perceived price variations. First, we asked vendors whether they changed the prices of stickers within a given day. Ten of them responded negatively. The only vendor who provided a different response claimed that he would change the price of stickers within a day if the number of units left of a specific sticker was too low. This vendor followed a distributor-based pricing strategy.

We also asked vendors whether they had changed the prices of stickers between days. Ten of them responded affirmatively, arguing that prices had been declining over time since mid-March when the distribution of stickers and albums started in Bogotá (the remaining vendor responded negatively). Even though most of them agreed on the price decline, they provided different explanations for this trend. Five of them argued that the reason for the downward trend was that the price of the box containing 520 stickers had reduced by approximately $30 \%$. Two vendors claimed that prices lowered as a consequence of greater competition given the large number of vendors, whereas two other vendors claimed that demand had been decreasing. The remaining vendor claimed that price fluctuation was mostly associated with the performance of the Colombian squad in the World Cup.

We introduced first these two questions in which vendors would be more likely to acknowledge price variation than when being asked about price changes that may hint discrimination based on buyers' attributes. Then, we proceed to ask if they charged different prices to males and females, and locals with respect to foreigners. All the respondents said that they charged the same prices regardless of gender. Similarly, all but one of the responders said that they charged the same prices regardless of nationality. The remaining vendor said:

[Excerpt 4] "Not really... the price is like the same. What changes is as people say... as the saying goes... to the highest bidder, right?... then let's say, those who are charged a little more, or something like that, maybe are the foreigners."

The audit experiment and the interviews provide different responses to whether sticker vendors discriminate against foreigners. The main challenge for interpreting the interviews' responses is to disentangle between a social 
desirability bias (i.e., vendors might believe that acknowledging price discrimination is objectionable) from a pattern of implicit (or unconscious) discrimination (Bertrand et al. 2005). An argument against the social desirability bias is that sellers acknowledge the trade of counterfeit stickers. This argument is explored in-depth in the next section.

\subsection{Counterfeit stickers}

The rarity of shiny foil stickers in the 2018 World Cup album gave origin to the presence of counterfeit copies among street vendors, as some of them confirmed. Regarding this rarity, one vendor said:

[Excerpt 5] "In the last World Cup, there were several teams that came out a lot and others that did not. However, this year all the teams came out, as well as all the players. What did not come out were the shiny ones. Let's say, from a single box, there were 18, 19 shiny stickers coming out. There are 50 in total, considering the first and last page, as well as the emblems. Usually, 18 came out from a box, at most 20 or 22 , you see?".

As a consequence of this rarity of shiny foil stickers, vendors confirm that people passed by offering them a set of 50 shiny foil counterfeit stickers. For instance, a vendor said:

[Excerpt 6] "They pass by asking: $<<$ Do you need shiny stickers? $>>$, and I answer: $<<$ Yes, but originals $>>$, and then they say: $<<$ Nooo, you know that I don't have those $>>$, so I respond: $<<$ Ahm no! I already have those, I need originals. > > They sell the set of 50 shiny stickers for 25 (thousand COP) or 20 (thousand COP)."

Learning about the existence of counterfeit stickers was one of our major motivations to conduct the interviews since price variation could reflect possession of counterfeits rather than price discrimination based on buyers' attributes, or even worse, a combination of both. Think, for instance, that the same price was quoted to locals and foreigners, but vendors offered original stickers to the former and counterfeits to the latter, then the two prices would not be comparable. We argue that this was not the case since counterfeits appeared in the market, but they were only offered after buyers claimed that shiny foil stickers were too expensive.

Three different vendors mentioned that they started to be offered a large sheet containing the fifty shiny foil stickers in the collection two weeks before the kick-off of the World Cup. The price of this sheet varied between geographic clusters, from 25,000 to 40,000 COP. ${ }^{16}$ Vendors also claimed that distributors started to give them similar large sheets with multiple shiny foil stickers when they bought boxes containing packets of stickers. According to a vendor, this was a compensation offered by the distributors, given the rarity of shiny foil stickers.

Seven of the interviewed vendors claimed that they were aware of counterfeits, but they were not selling them. The main reason exposed to not engage in the sale of counterfeits were reputational concerns. In most cases, they do not want to lose their clientele since they have been selling stickers in the same spot for at least three FIFA World Cups. Two of the vendors revealed that, although they were not selling counterfeits, sometimes they exchanged stickers with buyers ${ }^{17}$ and, as a result of these exchanges, they ended up with counterfeits. The following is the testimonial from a vendor who accidentally received counterfeits in an exchange:

[Excerpt 7] "Since I have the stall, I must sell what is original, but on the street, there are a lot of scanned stickers that vendors are selling, and there are people who do not know. Then what happens? one day I had a problem with a DIAN official. ${ }^{18} \mathrm{He}$ was a good client, and he brought colleagues here. It turns out that I, by mistake, for being there (points out to the street), and in the bookstore, I received some counterfeit stickers, I exchanged them, and then I was going to sell them. It turns out that precisely I gave them to him! and the official brought me the police!... but I did not know, I did not know that the stickers were fake. They are very well made, but nevertheless, there is a detail that you can recognize."

The remaining four vendors acknowledged that they were selling counterfeits. However, they sold both types of stickers and claimed that they offered the originals first. Only when buyers said the stickers were too expensive, they did offer counterfeits as a cheaper alternative. The following is the testimonial from one of these vendors:

[Excerpt 8] "Look, I'm very honest with the client. I didn't use to bring fake stickers, but clients asked me for fake ones... and now I bring fake ones. So I tell the client: $<<$ Well, do you want cheap or do you want expensive? Do you want the original or not? > > ..

\footnotetext{
${ }^{16}$ A street vendor located in downtown said that the price of these 50 fake stickers also fell over time like the original stickers:"they sell the package at 25,000 , or 20,000 . In the beginning, they sold it at 50,000."

17 With terms of trade highly advantageous for vendors, such as 3 for 1 sticker. However, buyers regularly accepted because they were close to complete the collection and had a large stock of duplicates.

18 DIAN is the Colombian Tax and Customs National Authority.
} 
then, it depends on the customer. I tell them:

$<<$ well, you are consciously buying a fake one $>>$."

The presence of counterfeits is not very likely to affect the outcomes in our audit experiment for two reasons. First, according to a couple of vendors, counterfeits were easily detectable based on the lower brightness and the lack of holograms, and it is therefore credible that they were not offered to buyers in our audit study. Second, our script did not allow buyers to bargain over prices. Therefore, the typical offer of counterfeits as a response to a price reduction was not likely to occur.

\subsection{Other insights from the stickers market}

This last subsection is devoted to the analysis of three additional lessons on how the stickers market works. Some of these insights yield more general lessons regarding seasonal street-vending, primarily linked to sporting events.

From the audit experiment and the interviews, we learned that the stickers market is subject to multiple sources of uncertainty. The spatial distribution of vendors, together with the low relocation costs in some zones, revealed strategic uncertainty in the competition for clients. Additionally, the vendors also disclosed they had made large investments and were concerned by the rapid drop in prices of the merchandise associated with the World Cup. In fact, they mentioned that they were forced to decrease prices sooner than usual due to the large competition that year and the number of counterfeit stickers circulating in the market.

Another source of uncertainty we could identify from the interviews was the connection between vendors' profits and expectations and the performance of the Colombian national squad in the World Cup. This link is important since vendors invested in merchandise based on the outcome of the Colombian national squad in the previous World Cup, which was exceptional. In addition, the performance during the 2018 FIFA World Cup not only shaped expectations about sales but also determined the price of the merchandise, particularly of stickers. Vendors were afraid of an early elimination of the Colombian squad, which would drastically decrease the demand for goods related to the World Cup. The converse appears to be also true for some vendors. For instance, a vendor replied the following when asked about adjusting the price of stickers:

[Excerpt 9] "It depends... At least now during the World Cup, as long as Colombia wins, (prices) go up."
And another one mentioned how investments were driven by expectations about the performance of the National squad four years before:

[Excerpt 10] "Four years ago, the jerseys were scarce. Colombia won, and the price went up... it immediately went up. So I said, this year, the same thing will happen, and it was not true. I received a loan of 10 million pesos, and I invested it in a lot of jerseys. I paid 23,000 pesos (each), and today I went to buy some small jackets for kids, and I realized that the (jerseys') price now is 4,000 pesos... Too bad!... Now I can cry over spilled milk. If they win today, I go and buy. From there, I recover some of what I... It's terrible, terrible. Do you know what that is? Look, we bought the jerseys for 23,000 pesos, and we are selling them for 25,000. Can you imagine what it is like waiting for four years to make a profit of 2,000 from a jersey (0.7 US Dollars)?”.

This testimonial also confirms the large investments in sporting events merchandise made by street vendors. Our second insight is that these loans, combined with the long periods that street vendors have stayed in this business, suggest that (in this seasonal market) informality is a choice rather than an outcome associated with exclusion of the formal labor force (Levy 2010; La Porta and Shleifer 2014). The ten interviewees that responded for how long they had been street vendors during the World Cup season mentioned on average 14.9 years. Nonetheless, some of them have other off-season jobs different from street-vending. They take advantage of the flexibility from informal labor markets to work on the streets when it is more profitable.

A final insight is how the costs of entry and exit from seasonal street-vending relate to the spatial location of vendors. In principle, if entry is not costly, vendors' location is subject to the "tragedy of the urban commons" (Webster 2007; Kim 2012). Two reasons alleviate this problem. On the one hand, attractive selling spots are less scarce given the sparse location pattern nearby stores of a high-end supermarket chain. Besides, most street vendors do not see each other as fierce competitors. This is the testimonial of a vendor when asked about her location nearby one of these stores:

[Excerpt 11] "My spot was next to the door of Banco de Bogotá, and then I got sick and went home. There, on the sidewalk, there was a thing on the (parking) blue zones, and I had a stall there, but then since I got cancer, I went home. Now I come here to work only during the World Cups [Interviewer: Ok... and is it better to be around other vendors like this? Because generally there is a lot of people here] A lot! Look, let me tell you one thing: what God has for you, he keeps it, no matter where you are." 
On the other hand, there are some areas where the relationship with policemen mediates location outcomes. In most cases, entry costs might be higher since policemen ask for merchandise (i.e., stickers or jerseys) to let them work on those areas. However, policemen might also give priority to vendors established in a given spot for a long time, under some conditions. A vendor revealed that she has to work, once a week, on a spot where sales are good only in December (otherwise policemen might reassign her spot). She also revealed that policemen transfer the costs of reducing occupation of the public space to vendors. This is her response:

[Excerpt 12] "Yes, (they let us work) under the condition that we do not let any other new (vendor) get in."

\section{Final discussion}

Street-vending of stickers is an informal market without posted prices, which allows sellers to exercise a discretionary power. We conducted two audit studies on sticker vendors to test the existence of price discrimination in this context. Study 1 aimed at detecting price discrimination based on two buyers' attributes: nationality and gender. We find evidence of price discrimination against Argentinians with respect to the local Colombian experimenters. Foreigners were charged on average $4.8 \%$ more per sticker, and the effects are significant for the most expensive and the least expensive stickers. We argue that sellers use the higher price fluctuation of the most expensive ones, for which they can claim scarcity, as an excuse to increase prices for foreigners. For the least expensive stickers, sellers infer that foreigners are less familiar with the low prices of regular stickers (i.e., those not printed in shiny foil), and is more likely that they receive quotations that are two or three times higher than the modal value.

By contrast, we did not find evidence of gender discrimination. Our script was designed to make sure that any price difference between male and female buyers was not driven by a problem of second-order moral hazard (Balafoutas et al. 2015), in which vendors infer that men quoted stickers for themselves, whereas women quoted stickers for someone else.

Study 2 aimed at detecting price discrimination based on a good's attribute: the length of the quoted sticker list. We hypothesized that vendors could have inferred that buyers having fewer stickers left to complete the collection would have a higher willingness to pay, which would have encouraged them to raise the price of the same sticker when it belonged to a shorter list. We do not find evidence of this more sophisticated discriminatory behavior.
We combined the audit studies with eleven interviews conducted with sticker vendors from the audited sample. The interviews shed light on crucial aspects to interpret the results from the audit studies. Interviewed vendors claim that they do not discriminate based on buyer's attributes. We argue that these responses might reflect implicit discrimination (Bertrand et al. 2005) rather than a social desirability bias. Vendors concerned about providing socially desirable answers would have not naturally claimed that they sold counterfeits in addition to official stickers, as occurred with about half of them. From a more general perspective, the combination of audit studies with interviews allowed us to better understand the functioning of this seasonal market. Although street vendors make large investments in merchandise related to the sporting event (including stickers), price variation is much better explained by the vendors' location around the city and not by altering prices to specific buyers in a considerable amount.

The recent use of audit experiments in developing countries introduces detectability as an important element for understanding behavior. For instance, Grossman and Honig (2017) show that rice sellers are more likely to discriminate against High-class non-coethnics, not by charging directly a higher price, but by delivering smaller quantities, conditional on paying the same amount for a scoop of rice. Similarly, we found that price discrimination based on nationality was most evident for the expensive stickers, those in which price fluctuations and scarcity can be used to argue discretionary prices. This evidence calls for further studies focused on the detectability of discrimination in informal markets.

Open questions include whether the subtleness of discrimination operates at a conscious or unconscious level, and whether the lower detection of discrimination emerges in developing countries as a response to the fear of retaliation from the buyer. When formal and informal markets coexist, this question becomes even more relevant since sanctioning mechanisms differ between markets. If such fear of retaliation exists, it would be interesting to understand whether the perceived threat is associated to direct punishment (i.e., verbal or physical aggression, or reports to the police) or indirect punishment (i.e., abstain from trade) (Balafoutas et al. 2014). Finally, fear of retaliation can lead to models of multidimensional statistical discrimination, in which buyers' (resp. vendors) attributes not only signal a willingness to pay (resp. to accept), but also indicate the likelihood and expected damage of retaliation. 


\section{Appendices}

\section{Appendix 1}

See Tables 6, 7, 8, 9 and Figures 2, 3, 4

We present three figures in this appendix. The first two figures illustrate vendors' location and their interaction with experimenters acting as buyers. The left side of Fig. 2 depicts a map of the Northeastern side of Bogotá, including the five clusters of sticker vendors. The right side of Figure 2 zooms in each one of the clusters to provide better information on vendors' spatial location,

Figure 3 shows a grid of buyers in the columns and vendors in the rows. The dots and diamonds indicate each vendor-buyer interaction registered in our experiment.

Figure 4 shows the cumulative distribution of quoted prices for the three least expensive stickers (i.e., those printed on regular paper), separately for Colombians and Argentinians.

\section{Appendix 2 \\ Script for experimenters acting as vendors}

In the following scripts, squared brackets correspond to instructions for the buyer that must not be read aloud. Sticker numbers separated by a slash (/) correspond to the randomization of similar stickers between lists. The text wrapped in $\langle<>>$ is mentioned only by Argentinian buyers.

Script \#1: Long list [Before starting: Take out both the handwritten list and the printed list from the envelope. Check that the vendor's ID matches the letters in the envelope. Mark all the information that is on the back of

Table 6 Day on which each experimenter quoted prices and the route that followed

\begin{tabular}{|c|c|c|c|c|}
\hline Day & Tueday June 5 & Wednesday June 6 & Thursday June 7 & Friday June 8 \\
\hline Experimenter / Route & $\begin{array}{l}\text { COL-F-LL / North to } \\
\text { South }\end{array}$ & COL-M-LL / South to North & COL-F-SL / North to South & $\begin{array}{l}\text { ARG-F- } \\
\text { LL / North to } \\
\text { South }\end{array}$ \\
\hline Experimenter Route & & ARG-M-LL / North to South & COL-M-SL / South to North & \\
\hline
\end{tabular}

COL-F-LL refers to the Colombian woman in the Long List treatment. The COL-M-LL experimenter went back to Downtown during the morning on Friday, June 8 , since there were scarce vendors during the morning on Wednesday, June 6 . There was a large police presence in the area, which caused the vendors to disperse and made it difficult to find them. Also, the ARG-M-LL experimenter went back to Downtown during the morning on Thursday, June 7, since there were scarce vendors during the late afternoon the day before

Table 7 Proportion of vendor-buyer interactions with unavailable stickers

a Vendor did not have the sticker and did not give any price

\begin{tabular}{|c|c|c|c|c|c|c|}
\hline & \multicolumn{3}{|c|}{ Vendors } & \multicolumn{3}{|c|}{ Stickers } \\
\hline & $C O L-F-L L$ & ARG-M-LL & COL-M-SL & COL-F-LL & ARG-M-LL & COL-M-SL \\
\hline Downtown & $0 / 21$ & $1 / 12$ & $1 / 6$ & $0 / 189$ & $6 / 108$ & $1 / 24$ \\
\hline Street 72 nd & $0 / 13$ & $0 / 10$ & $0 / 13$ & $0 / 117$ & $0 / 90$ & $0 / 52$ \\
\hline Street 85th & $0 / 9$ & $1 / 9$ & $1 / 7$ & $0 / 81$ & $8 / 81$ & $1 / 28$ \\
\hline Street 93rd & $1 / 7$ & $0 / 8$ & $1 / 7$ & $6 / 63$ & $0 / 72$ & $1 / 28$ \\
\hline Street 147th & $0 / 8$ & $0 / 7$ & $0 / 7$ & $0 / 72$ & $0 / 63$ & $0 / 28$ \\
\hline Total & $1 / 58=1.72 \%$ & $2 / 46=4.35 \%$ & $3 / 40=7.5 \%$ & $6 / 522=1.15 \%$ & $14 / 414=3.38 \%$ & $3 / 160=1.87 \%$ \\
\hline \multicolumn{7}{|c|}{ b Vendor did not have the sticker but did mention a price } \\
\hline & & \multicolumn{2}{|l|}{ Vendors } & & \multicolumn{2}{|l|}{ Stickers } \\
\hline & COL-F-LL & ARG-M-LL & COL-M-SL & $C O L-F-L L$ & ARG-M-LL & COL-M-SL \\
\hline Downtown & $0 / 21$ & $1 / 12$ & $1 / 6$ & $0 / 189$ & $4 / 108$ & $1 / 24$ \\
\hline Street 72nd & $0 / 13$ & $1 / 10$ & $2 / 13$ & $0 / 117$ & $3 / 90$ & $3 / 52$ \\
\hline Street 85th & $0 / 9$ & $0 / 9$ & $0 / 7$ & $0 / 81$ & $0 / 81$ & $0 / 28$ \\
\hline Street 93rd & $1 / 7$ & $1 / 8$ & $1 / 7$ & $3 / 63$ & $6 / 72$ & $1 / 28$ \\
\hline Street 147th & $1 / 8$ & $0 / 7$ & $0 / 7$ & $1 / 72$ & $0 / 63$ & $0 / 28$ \\
\hline Total & $2 / 58=3.45 \%$ & $3 / 46=6.52 \%$ & $4 / 40=10 \%$ & $4 / 522=0.77 \%$ & $13 / 414=3.14 \%$ & $5 / 160=3.12 \%$ \\
\hline
\end{tabular}

Columns correspond to the three buyers who collected this information in detail. COL-F-LL refers to the Colombian woman in the Long List treatment. For the Long List, the number of missing values in bold font coincide with the number of missing values in the database for the experimenter. For the Short List, even though nine vendors did have the four stickers, they only mentioned the price for the full list, and not for each of them individually 
Table 8. Balance across attributes made salient in Studies 1 and 2. Coefficients correspond to linear probability models.

\begin{tabular}{|c|c|c|c|c|}
\hline \multirow{3}{*}{$\begin{array}{l}\text { Sample } \\
\text { Dep. Variable }\end{array}$} & (1) & (2) & \multirow{3}{*}{$\begin{array}{l}\text { (3) } \\
\text { Short List } \\
\text { Gender (=1 if Male Buyer) }\end{array}$} & \multirow{3}{*}{$\begin{array}{l}\text { (4) } \\
\text { Full Sample } \\
\text { List Length (=1 if Long List) }\end{array}$} \\
\hline & \multicolumn{2}{|l|}{ Long List } & & \\
\hline & Gender ( $=1$ if Male Buyer) & Nationality (=1 if Foreigner) & & \\
\hline $\begin{array}{l}\text { (Perceived) Vendor's age (= } \\
1 \text { if 35) }\end{array}$ & $0.232^{* * *}(0.072)$ & $-0.040(0.076)$ & $-0.056(0.105)$ & $0.024(0.076)$ \\
\hline $\begin{array}{l}\text { Vendor's gender ( }=1 \text { if } \\
\text { Male) }\end{array}$ & $0.032(0.073)$ & $-0.046(0.075)$ & $-0.068(0.106)$ & $-0.018(0.076)$ \\
\hline Isolated vendor & $0.094(0.075)$ & $0.008(0.077)$ & $0.026(0.115)$ & $-0.084(0.076)$ \\
\hline Journey (=1 if Afternoon) & $-0.129(0.092)$ & $-0.010(0.091)$ & $0.379^{* * *}(0.112)$ & $0.170 * *(0.085)$ \\
\hline Constant & $0.373^{* * *}(0.099)$ & $0.522^{* * *}(0.101)$ & $0.262^{* * *}(0.117)$ & $0.454^{* * *}(0.092)$ \\
\hline Observations & 199 & 199 & 88 & 194 \\
\hline R-squared & 0.058 & 0.003 & 0.129 & 0.024 \\
\hline
\end{tabular}

${ }^{*} p<.1,{ }^{* *} p<.05,{ }^{* * *} p<.01$. Robust standard errors are shown in parenthesis. The dependent variable in all specifications is the vendor's price quoted in thousands of Colombian pesos (kCOP). The sample size in model (4) is 194 observations because Foreign buyers were excluded from the regression

Table 9 Effect of vendor-buyer gender interactions on the price quoted by the vendor

\begin{tabular}{lllll}
\hline Variables & \multicolumn{2}{l}{ (1) Price [kCOP] } & \multicolumn{2}{l}{ (2) Price [kCOP] } \\
\hline Foreigner & $0.203^{*}$ & $(0.113)$ & $0.203^{*}$ & $(0.121)$ \\
Male Buyer x Female Vendor & 0.336 & $(0.312)$ & 0.336 & $(0.381)$ \\
Female Buyer x Male Vendor & 0.153 & $(0.166)$ & 0.153 & $(0.178)$ \\
Male Buyer x Male Vendor & -0.097 & $(0.155)$ & -0.097 & $(0.157)$ \\
Constant & -0.200 & $(0.330)$ & -0.200 & $(0.288)$ \\
R-squared & 0.799 & & 0.799 & \\
Controls and Vendor FE & Yes & & Yes & \\
Errors & Standard & & Robust & \\
Number of observations & 1712 & & 1712 & \\
\hline
\end{tabular}

${ }^{*} p<$.1. Standard errors are shown in parentheses. The dependent variable in all specifications is the vendor's price quoted in thousands of Colombian pesos (kCOP). Controls in all regressions: geographic cluster, day and sticker fixed effects, (perceived) age and gender of the vendor, whether the vendor has nearby vendors, and journey

the printed list. Hide the printed list and do not get too close to the vendor.]

Good morning/afternoon, how are you?

My husband/wife and I are looking for the missing stickers to complete our kid's PANINI album.

$\mathrm{He} / \mathrm{She}$ is also looking for the stickers right now, so for the moment, I am only quoting. Do you complete lists?

[If the vendor says "Yes," continue the script. Otherwise, say goodbye and look for the next vendor ID.]

OK, I tell you which ones I need, and you tell me the price.

I am going to write them down because they are for my kid, and I also have to talk to my husband/wife.

[Start writing down the prices on the list assigned to that vendor. If the vendor does not have a sticker, ask her for the price that she would charge for it if she finds it for you. If the vendor says she could not find it, ask for the price she charged the last time she sold it.]

Okay, let's start with the team emblems. I need three.

First of all, I need the emblem of my country: Colombia/Argentina. It's number 620/260. How much is it?

I also need the emblem of Argentina/Colombia. It's number 260/620. How much is it? And the emblem of Peru/Uruguay. It's number $220 / 80$. How much is it?

I am missing one legend, $<<$ the best player in history, $>>$ Maradona. It's number 664 .

$<<$ The guy is a genius! $>>$ How much is it?

Okay. Let's continue from the beginning. I need two from the front page.

Number 2, which is the Trophy; and number 7, which is the Ball. How much for each one? I also need one stadium, number $11 / 12$. How much is it?

I need (the picture of) one team, it is Denmark/Iceland, number $241 / 281$. How much is it?

And finally, I need one player, number 129/574. It's a player from Spain/England. How much is it?

[Annotate all the prices in the hand-written list and terminate the interaction.]

Thank you! I may come back, or my husband/wife will come back. At what time of the day can I find you here?

Thanks again, have a good day.

[Walk away from the seller and write all the prices on the printed list.]

Script \#2: Short list Since the protocol is very similar, we only provide below the part of the script concerning the quotation of the four stickers in the Short List treatment. Unlike the Long List treatment, in this case we quote stickers in ascending order according to the album's numbers. We altered the order because it would be easier for the 


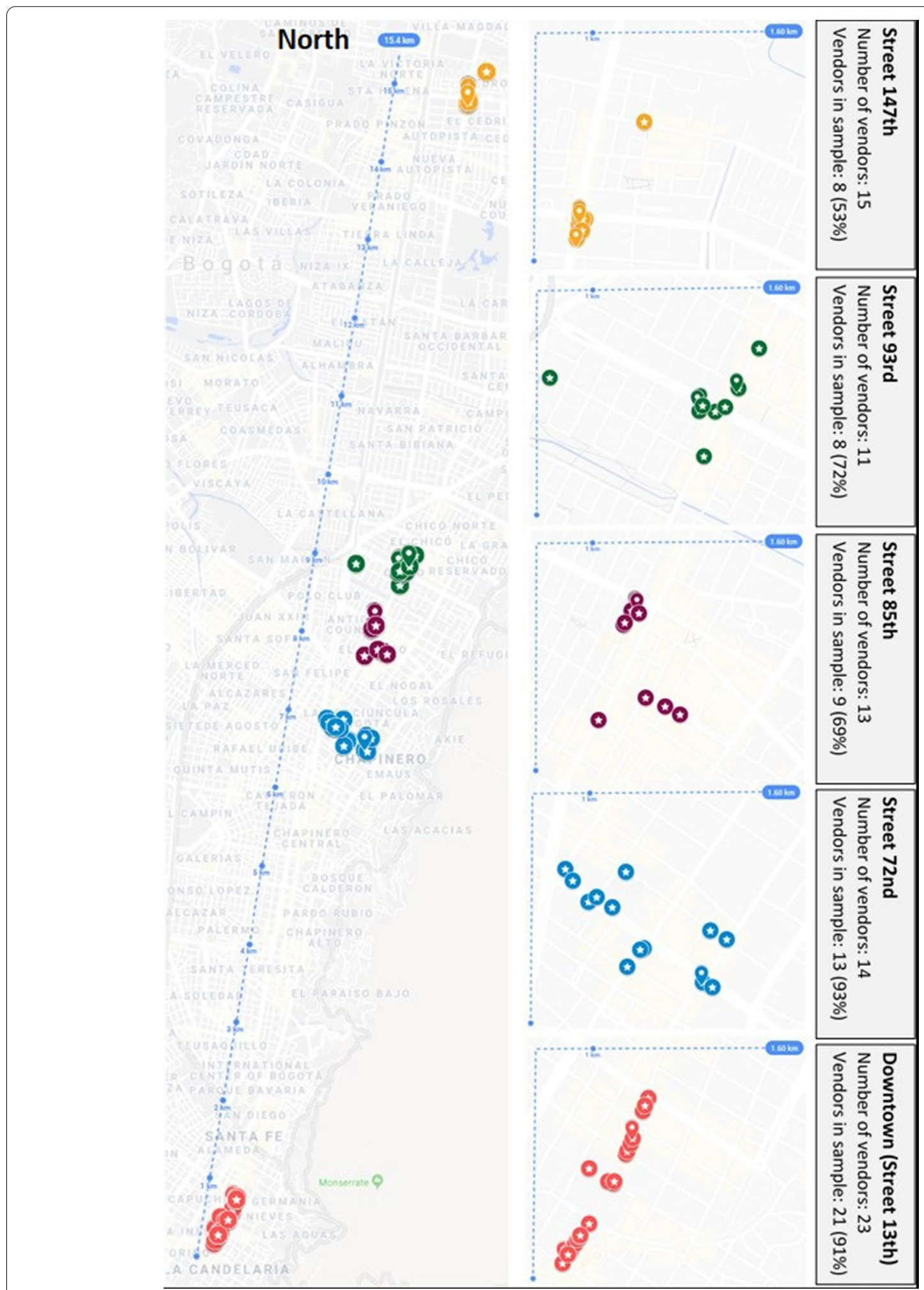

Fig. 2 Sampling of sticker vendors in five clusters in Bogotá. The maximum distance between clusters is $15 \mathrm{~km}$. Panels on the right side represent an $800 \times 800 \mathrm{~m}$ grid for each cluster 


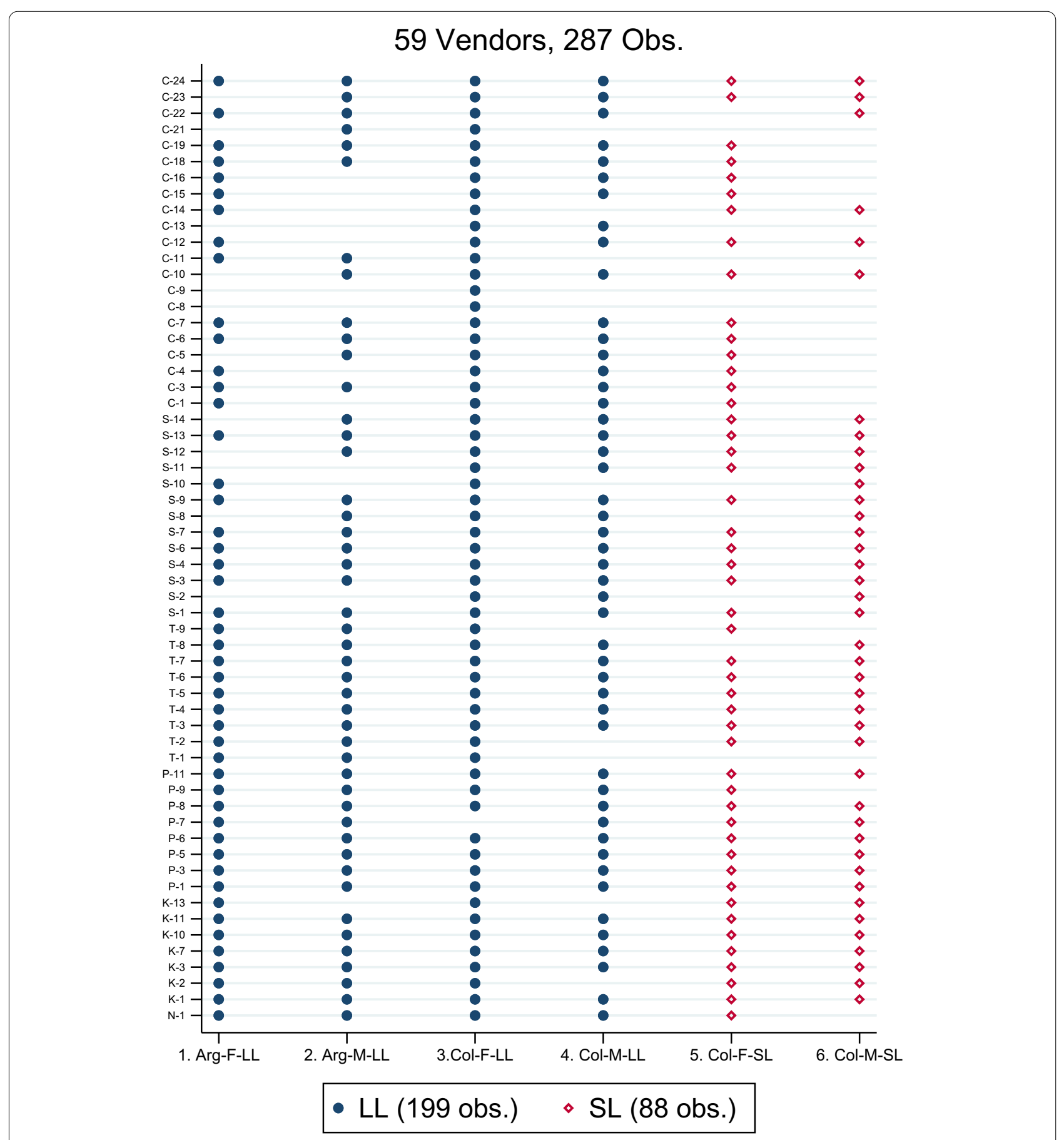

Fig. 3 Mapping between buyers and vendors. Columns represent each one of the buyers, and rows represent each one of the sellers. Circles denote a vendor-buyer interaction in the Long List treatment, and hollow diamonds denote a vendor-buyer interaction in the Short List treatment.

vendor to look for the stickers, and in the Short List treatment, there was no need to prime the buyer's nationality.

Okay, let's start with the emblems on the first page.
I need the Panini Knight Logo/FIFA Fair Play, it’s number $0 / 1$. How much is it? I also need the Trophy, number 2. How much is it? 


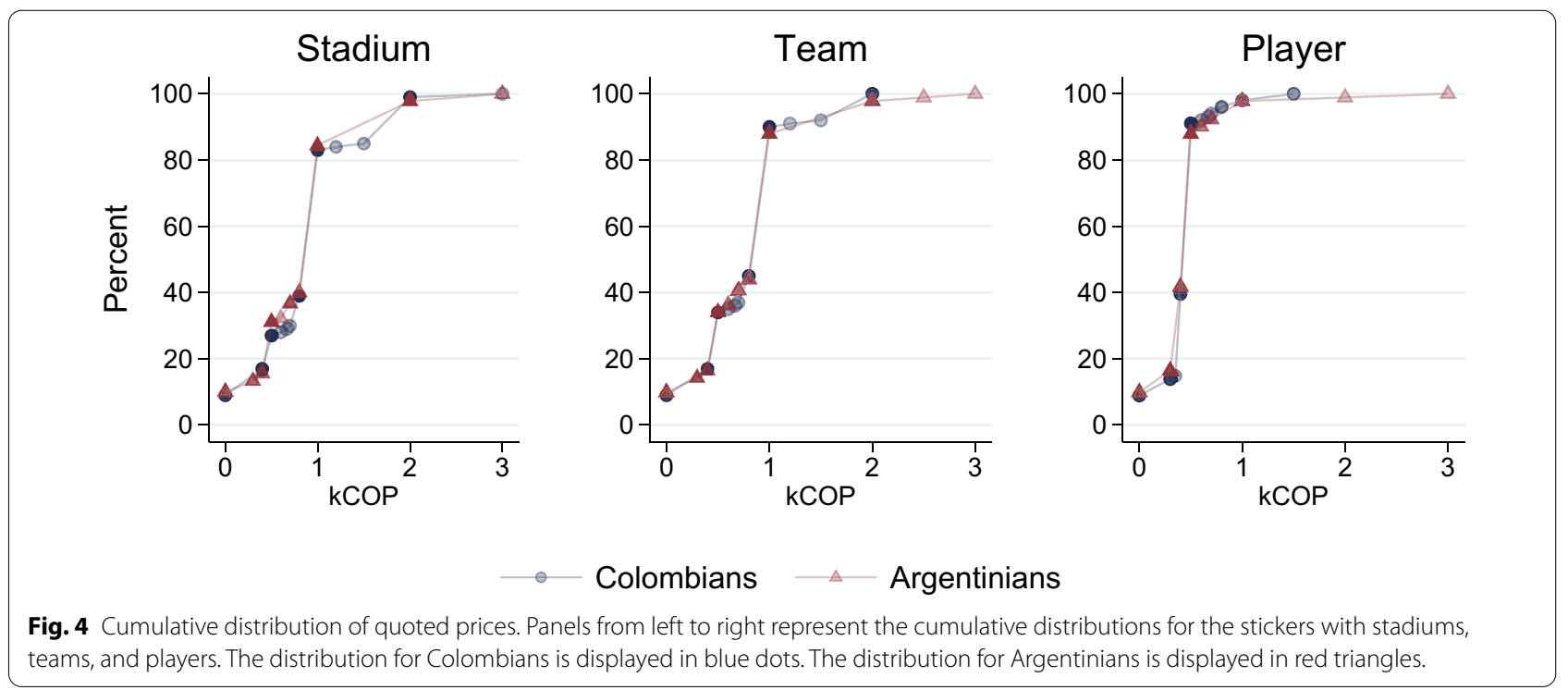

Good. I also need the logo of Brazil/Germany, it's number $340 / 420$. How much is it? Finally, I need the logo of Colombia. How much is it?

\section{Appendix 3}

See Table 10.

\section{Questions for the structured interview}

Questions in parenthesis were only asked when applied.

- What is your usual work schedule? Why that schedule?

- Does anyone else work here with you? Are you usually accompanied?
- Do you share your business with someone else? Family? Partner? Friend? Employee?

- At what time do you sell more?

- How did you establish your prices?

- Do you get upset if people tell you that they are only going to quote?

- Do you change the prices throughout the day?

- Do you charge more per sticker to some people than others? Women with respect to men? Foreigners with respect to locals? To young people or to older people?

- Any difference in prices before it started and during the World Cup?

Table 10 Schedule of conducted interviews

\begin{tabular}{|c|c|c|c|c|c|}
\hline Date & Number of Interactions & Time & Zone & Gender & Perceived age \\
\hline & 6 & 1:30 p.m & Street 93rd & Female & Old woman \\
\hline \multirow[t]{5}{*}{ July 2, 2018 (holiday) } & 6 & 2:00 p.m & Street 93rd & Male & Young man \\
\hline & 6 & 3:00 p.m & Street 147th & Female & Middle Age \\
\hline & 6 & 3:30 p.m & Street 147th & Male & Middle Age \\
\hline & 6 & 9:50 a.m & Downtown & Male & Middle Age \\
\hline & 5 & 10:15 a.m & Downtown & Female & Old woman \\
\hline \multirow[t]{4}{*}{ July 3, 2018 (business day) } & 6 & 11:10 a.m & Street 72nd & Female & Middle Age \\
\hline & 6 & 11:40 a.m & Street 72nd & Male & Old man \\
\hline & 6 & 12:00 p.m & Street 85th & Male & Middle Age \\
\hline & 6 & 12:10 p.m & Street 85th & Male & Middle Age \\
\hline $\begin{array}{l}\text { July 13, } 2018 \text { (business } \\
\text { day) }\end{array}$ & 5 & 4:30 p.m & Street 147th & Female & Middle Age \\
\hline
\end{tabular}


- When were the highest prices reached and when were the lowest?

- Do you sell or used to sell counterfeit stickers?

- How can you find the counterfeits? Who sells them?

- Why are you located here?

- (Why are you so close to the supermarket?)

- (If you know there are many vendors here, why not go further?)

- For how long have you established your business here?

- What do you do outside the World Cup season? Do you sell something else?

- Does the police often come to carry out inspections? What do you do when the police arrive?

- Do you pay, or paid before, social security? Pension contributions? Health insurance?

- Have you ever rented a place to sell your merchandise? (How much do you pay for rent?)

- Why did you decide to dedicate yourself to selling things in this way?

- Do you live far away?

- What do you do with the merchandise after the journey? Where do you leave it?

\section{Original Excerpts in Spanish}

[Excerpt 1]"Pues es que ya uno tiene un recorrido con el mundial, ¿sí?... que por lo menos uno coge y destapa cajas... porque es que uno destapa... tiene es que destapar cajas o pacas como se dice... porque una paca trae 12 cajas. Entonces pues digamos uno destapa 3, 4 pacas. Entonces, ya arreglando las fichas por números y todo, ahí uno deduce cuál es el equipo que más sale, los jugadores que más salen, las fichas que menos salen. Entonces de ahi los que más saca son los más baratos y los que menos salen son los má costosos."

[Excerpt 2] "Establecimos los precios de acuerdo a la experiencia de ventas anteriores y averiguando con otros vendedores."

[Excerpt 3] "Pues yo he tratado de cambiar los precios, porque por lo menos con las láminas los escudos son los difíciles y pues ahi yo soy la que má caro vende. El resto sí por la guerra de precios, entonces se venden barato. Es el que más vende... no es el que más gane, sino el que más vende... el que quiera pelear a un cliente, el que le dé más barato, aparte que los clientes le ponen precio a la mercancía... o sea uno ya no puede ponerle precio, porque ellos vienen ya a ponerle el precio a uno."

[Excerpt 4] "No, de por sí, no... el precio es como el mismo. Lo que cambia es como se dice... como dice el dicho... al mejor postor, ¿no?... entonces pues digamos, a los que se les cobra un poquito más o algo así, de pronto sí son los extranjeros."

[Excerpt 5] "En el mundial pasado había varios equipos que salían mucho y otros que no salían. En cambio este año salieron todos los equipos, todos los jugadores. Lo que no salieron fue las doradas. Digamos, de una sola caja, estaban saliendo por ahí 18, 19 escudos. Son 50 en total, entre primera, última página y escudos. Salían 18, por mucho salían 20, 22, ¿si ves?”

[Excerpt 6] "Pasan preguntando: "necesitan escudos?", yo contesto: "sí, pero originales", entonces ellos dicen: "Nooo, usted sabe que yo no tengo de esos", entonces respondo: "ahm no!, yo ya tengo de esos, necesito originales". Eso venden el paquete de 50 láminas a 25 o a 20 "

[Excerpt 7] "A mí por el local me toca vender sólo lo que es original, pero en la calle hay mucha lámina escaneada que los vendedores están ofreciendo y hay gente que no conoce. Entonces, ¿qué pasa? a mí un día me pasó un inconveniente con un funcionario de la DIAN. Era un buen cliente y é me traía compañeros. Resulta que yo por equivocación y por estar allá (señala la calle) y estar en la librería, recibí unas láminas y yo las intercambié y después las iba a vender. ¡Resulta que precisamente se las di a é! y el funcionario jme trajo la policía!... pero yo no sabia, yo no sabía que las láminas eran falsas. Es que son muy bien hechas, pero sin embargo tiene un detalle que uno puede reconocer."

[Excerpt 8] "Mire yo soy muy honesta con el cliente. Yo acá no trabaja las chiviadas, pero a mí me pedian chiviadas... y ahora yo traigo chiviadas. Entonces yo le digo al cliente: $<<$ bueno, quiere barato o quiere caro?, ¿quiere original o no original? $>>\ldots$ entonces ya depende del cliente. Le digo: < < bueno, ya a conciencia lleva chiviada... >>"

[Excerpt 9] "Es dependiendo... por lo menos ahorita en el mundial, a medida que va ganando Colombia, va subiendo."

[Excerpt 10] "Hace cuatro años las camisetas estuvieron escasas. Ganó Colombia y se subió el precio... enseguida subió el precio. Entonces yo dije, este año va a pasar lo mismo, y mentiras. A mí me hicieron un préstamo de 10 millones de pesos y lo invertí en un poco de camisetas. La pagué a 23,000 pesos $y$ hoy fui a comprar unas chaqueticas para niño $y$ me doy cuenta que está a 4,000 pesos... iya qué!... ya puedo llorar sobre la leche derramada. Si ganan voy y compro. Ahí repongo algo de lo que... terrible... terrible... ¿sabe qué es eso? mire, compramos camiseta a 23,000 pesos y la estamos vendiendo a 25,000... ¿se 
imagina sumercé esperar cuatro años para ganarse uno en una camiseta 2,000 pesos?"

[Excerpt 11] "Mi puesto era en la puerta del Banco Bogotá y me enferme' y me fui para la casa. Ahí en la bahía había una cosa de las zonas azules y ahí yo tenía un puesto, después como me dio cáncer me fui pa' la casa. Ahora no vengo sino a trabajar los mundiales acá. [Entrevistadora: ¿y es mejor estar así rodeado? Porque aqui generalmente hay más gente, ¿no?] ¡Muchísima! Mire sumercé, yo le digo una cosa: lo que Dios le tiene a uno, se lo guarda, así esté uno donde esté."

[Excerpt 12] "Sí, nos dejan trabajar aquí con la condición de que no dejemos meter a ninguno nuevo."

\section{Acknowledgements}

We gratefully acknowledge support from Santiago Sautua, Yuliet Verbel, and Juan Baquero during the execution of the field experiment. We also thank Diego Aycinena, Francesco Bogliacino, Simeon Schachtele, and participants in the LACEA-BRAIN workshop for their valuable comments.

The information and opinions presented herein are entirely those of the authors. Financial Support from the program "Inclusión productiva y social: programas y políticas para la promoción de una economía formal, código 60185, que conforma la Alianza EFI, bajo el Contrato de Recuperación Contingente No. FP44842-220-2018." is gratefully acknowledged

\section{Authors' contributions}

All authors have participated in (a) conception, design, and analysis of the data; (b) drafting the article or revising it critically for important intellectual content; and (c) approval of the final version. All authors read and approved the final manuscript.

\section{Funding}

Financial Support from the program "Inclusión productiva y social: programasy políticas para la promoción de una economía formal, código 60185, que conforma la Alianza EFI, bajo el Contrato de Recuperación Contingente No. FP44842-2202018." is gratefully acknowledged.

\section{Availability of data and materials}

Data and code are available in an Open Science Foundation repository: https ://osfio/gzhfs/.

\section{Competing interests}

The authors have no affiliation with any organization with a direct or indirect financial interest in the subject matter discussed in the manuscript.

\section{Author details}

${ }^{1}$ Department of Economics, Texas A\&M University, College Station, TX, USA.

${ }^{2}$ Department of Economics, Universidad del Rosario, Bogotá, Colombia.

Received: 30 October 2019 Accepted: 12 January 2021

Published online: 14 March 2021

\section{References}

Apollo, M.: Dual pricing-two points of view (Citizen and Non-citizen) case of entrance fees in tourist facilities in Nepal. Procedia Soc Behav Sci $\mathbf{1 2 0}$ 414-422 (2014)

Arrow, Kenneth. 1973. The theory of discrimination in labor markets. In: O. Ashenfelter, A. Rees (Eds.). Princeton, NJ: Princeton University Press.

Auspurg, K., Hinz, T., Schmid, L.: Contexts and conditions of ethnic discrimination: Evidence from a field experiment in a German housing market. J Hous Econ. 35, 26-36 (2017)
Ayres, I., Siegelman, P.: Race and gender discrimination in bargaining for anew car. Am Econ Rev 85, 304-321 (1995)

Azmat, G., Petrongolo, B.: Gender and the labor market: What have we learned from field and lab experiments? Labour Econ 30, 32-40 (2014)

Baert, S., De Pauw, A.-S.: Is ethnic discrimination due to distaste or statistics? Econ Lett 125(2), 270-273 (2014)

Balafoutas, L., Kerschbamer, R., Sutter, M.: Second-degree moral hazard in a real-world credence goods market. Econ J. 127(599), 1-18 (2015)

Balafoutas, L., Nikiforakis, N., Rockenbach, B.: Direct and indirect punishment among strangers in the field. Proc Natl Acad Sci. 111(45), 15924-15927 (2014)

Baldini, M., Federici, M.: Ethnic discrimination in the Italian rental housing market. J Hous Econ. 20(1), 1-14 (2011)

Balsa, A.I., McGuire, T.G.: Statistical discrimination in health care. J Health Econ 20(6), 881-907 (2001)

Baranzini, A., Schaerer, C., Ramirez, J.V., Thalmann, P.: Do foreigners pay higher rents for the same quality of housing in Geneva and Zurich? Swiss J Econ Statist 144(4), 703-730 (2008)

Becker, G.S.: The economics of discrimination. University of Chicago Press, Chicago (1957)

Bertrand, M., Chugh, D., Mullainathan, S.: Implicit discrimination. Am Econ $\operatorname{Rev}$ 95(2), 94-98 (2005)

Bertrand, M., Mullainathan, S.: Are Emily and Greg more employable than Lakisha and Jamal? A field experiment on labor market discrimination. Am Econ Rev 94(4), 991-1013 (2004)

Castillo, M., Petrie, R., Torero, M., Vesterlund, L.: Gender differences in bargaining outcomes: a field experiment on discrimination. J Public Econ 99, 35-48 (2013)

Charness, Gary, and Peter Kuhn. 2011. "Lab Labor: What Can Labor Economists Learn from the Lab?" In Handbook of Labor Economics, Vol. 4, ed. Orley Ashenfelter and David Card, 229-330. Amsterdam: Elsevier. North-Holland.

Chen, L.-Z., Wei-Min, Hu., Szulga, R., Zhou, X.: Demographics, gender and local knowledge - price discrimination in China's car market. Econ Lett 163, 172-174 (2018)

Csizma, K.A., Wittig, A.F., Schurr, K.T.: Sport stereotypes and gender. J Sport Exerc Psychol 10(1), 62-74 (1988)

Currie, J., Lin, W., Zhang, W.: Patient knowledge and antibiotic abuse: evidence from an audit study in China. J Health Econ 30(5), 933-949 (2011)

Fang, Hanming, and Andrea Moro. 2011. "Theories of Statistical Discrimination and Affirmative Action: A Survey." Pp. 133-200 in Handbook of Social Economics, Vol. 1A, edited by J. Benhabib, A. Bisin, and M. O. Jackson. Amsterdam: North-Holland, Elsevier.

Flage, A.: Ethnic and gender discrimination in the rental housing market: Evidence from a meta-analysis of correspondence tests, 2006-2017. J. Hous. Econ. 41, 251-273 (2018)

GrabowKu" hl, H.M.: You don't bend it like beckham if you're female and reminded of it: stereotype threat among female football players. Front Psychol 10, 1963 (2019)

Grossman, S., Honig, D.: Evidence from Lagos on discrimination across ethnic and class identities in informal trade. World Dev. 96, 520-528 (2017)

Grytten, J., Skau, I., Sørensen, R.: Do expert patients get better treatment than others? Agency discrimination and statistical discrimination in obstetrics. J Health Econ 30(1), 163-180 (2011)

Kim, A.M.: The mixed-use sidewalk: Vending and property rights in public space. J Am Plan Assoc 78(3), 225-238 (2012)

Kim, S.-H., Fernanda, L., de Leon, L.: In-group and out-group biases in the marketplace: a field experiment during the World Cup. Oxford Economic Papers 71(3), 528-547 (2018)

La Rafael , P., Shleifer , A.: Informality and development. J Econ Perspect 28(3), 109-126 (2014)

Levy, S.: Good intentions, bad outcomes: social policy, informality, and economic growth in Mexico. Brookings Institution Press, Washington (2010)

List, J.A.: The nature and extent of discrimination in the marketplace: Evidence from the field. Quart J Econ. 119(1), 49-89 (2004)

List, J.A., Rasul, I.: Field experiments in labor economics. In: Handbook of labor economics, vol. 4, pp. 103-228. Elsevier, Amsterdam (2011)

Martínez, L., Short, J.R., Estrada, D.: The urban informal economy: Street vendors in Cali, Colombia. Cities 66, 34-43 (2017) 
Mullainathan, S., Noeth, M., Schoar, A.: The market for financial advice: an audit study. National Bureau of Economic Research, Cambridge (2012)

Oxford, S., McLachlan, F.: "You Have to Play Like a Man, But Still be a Woman": young female colombians negotiating gender through participation in a sport for development and peace (SDP) organization. Sociol Sport J 35(3), 258-267 (2018)

Siegelman, P., Heckman, J.: The urban institute audit studies: their methods and findings. Clear Convinc Evid 187, 258 (1993)

Turchin, Peter. 2016. Ultrasociety: How 10,000 Years of War Made Humans the Greatest Cooperators on Earth. Chaplin, CT: Beresta Books.
Webster, C.: Property rights, public space and urban design. Town Plan Rev 78, 81-101 (2007)

Yip, C.M., Wong, R.-K.: Gender-oriented statistical discrimination theory: Empirical evidence from the Hong Kong labor market. Res Soc Stratif Mob 37, 43-59 (2014)

\section{Publisher's Note}

Springer Nature remains neutral with regard to jurisdictional claims in published maps and institutional affiliations.

\section{Submit your manuscript to a SpringerOpen ${ }^{\circ}$ journal and benefit from:}

- Convenient online submission

- Rigorous peer review

- Open access: articles freely available online

- High visibility within the field

- Retaining the copyright to your article

Submit your next manuscript at $\boldsymbol{\nabla}$ springeropen.com 